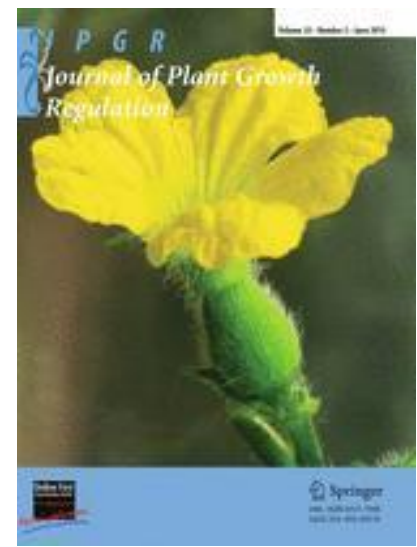

\title{
Defensive Responses in Groundnut Against Chewing and Sap-Sucking Insects
}

Abdul Rashid War ${ }^{(1)(2)}$ Michael Gabriel Paulraj ${ }^{(2)}$ Savarimuthu Ignacimuthu ${ }^{(2)}$ Hari Chand Sharma ${ }^{(1)}$

1. International Crops Research Institute for the Semi-Arid Tropics (ICRISAT), Patancheru, 502324, Andhra Pradesh, India

2. Entomology Research Institute, Loyola College, Chennai, 600034, Tamil Nadu, India

Journal of Plant Growth Regulation

June 2013, Volume 32, Issue 2, pp 259-272

DOI: http://dx.doi.org/10.1007/s00344-012-9294-4

This is author version post print archived in the official Institutional Repository of ICRISAT www.icrisat.org 


\title{
Defensive responses in groundnut against chewing and sap sucking insects
}

Abdul Rashid War ${ }^{a, b}$, Michael Gabriel Paulraj ${ }^{\mathrm{b}}$, Savarimuthu Ignacimuthu ${ }^{\mathrm{b}}$, Hari Chand Sharma ${ }^{\mathrm{a}^{*}}$

The affiliations and addresses of the authors:

\author{
Abdul Rashid War, Hari Chand Sharma \\ ${ }^{a}$ International Crops Research Institute for the Semi-Arid Tropics (ICRISAT), \\ Patancheru, Andhra Pradesh, India-502324
}

\author{
Abdul Rashid War. Michael Gabriel Paulraj Savarimuthu Ignacimuthu \\ ${ }^{\mathrm{b}}$ Entomology Research Institute, Loyola College, \\ Chennai, Tamil Nadu, India 600034
}

The affiliation of corresponding author

\section{Hari C Sharma}

${ }^{\mathrm{a}}$ International Crops Research Institute for the Semi-Arid Tropics (ICRISAT),

Patancheru, Andhra Pradesh, India-502324

Tel. No.: +9130713314

Fax.: +9130713075

*E-mail: $\underline{\text { H.Sharma@cgiar.org }}$

Running head: Induced resistance in groundnut against insect pests 


\title{
Defensive responses in groundnut against chewing and sap sucking insects
}

\author{
Abdul Rashid War ${ }^{a, b}$, Michael Gabriel Paulraj ${ }^{\mathrm{b}}$, Savarimuthu Ignacimuthu ${ }^{\mathrm{b}}$, Hari Chand Sharma ${ }^{\mathrm{a}^{*}}$ \\ ${ }^{a}$ International Crops Research Institute for the Semi-Arid Tropics (ICRISAT), Patancheru, Andhra Pradesh, India- \\ 502 324; ${ }^{b}$ Entomology Research institute, Loyola College, Chennai, Tamil Nadu, India-600 034 \\ *Corresponding author E-mail: H.Sharma@cgiar.org
}

\begin{abstract}
Induced resistance is one of the important components of host plant resistance to insects. We studied the induced defensive responses in groundnut genotypes with different levels of resistance to the leaf defoliator, Helicoverpa armigera and a sap sucking insect, Aphis craccivora to gain an understanding of the induced resistance to insects, and its implications for pest management. The activity of the defensive enzymes [peroxidase (POD), polyphenol oxidase (PPO), phenylalanine ammonia lyase (PAL), superoxide dismutase (SOD), ascorbate peroxidase (APX), and catalase (CAT)], and the amounts of total phenols, hydrogen peroxide $\left(\mathrm{H}_{2} \mathrm{O}_{2}\right)$, malondialdehyde (MDA), and proteins were recorded at six days after infestation. Induction of enzyme activities and the amounts of secondary metabolites were greater in the insect-resistant genotypes; ICGV 86699, ICGV 86031, ICG 2271, and ICG 1697 infested with $H$. armigera and $A$. craccivora than in the susceptible check, JL 24 . The resistant genotypes suffered lower insect damage and resulted in lower Helicoverpa larval survival and weights than those larvae fed on the susceptible check, JL 24. Number of aphids was significantly lower on insect-resistant genotypes than that on the susceptible check, JL 24. The results suggested that groundnut plants respond to infestation by H. armigera and A. craccivora in almost similar way, however, the degree of the response differed across the genotypes and insects, and this defense response is attributed to various defensive enzymes and secondary metabolites.
\end{abstract}

Key words: Groundnut, Helicoverpa armigera, Aphis craccivora, herbivory, induced resistance, oxidative enzymes, secondary metabolites 


\section{Introduction}

About 6 million insect species are present in the world, of which 50\% are herbivorous (Chapman 2006) and are a major threat to the crop production. They cause an estimated loss of over US\$14 billion worldwide annually, despite application of insecticides costing over \$2 billion annually (Sharma and others 2005). Groundnut (Arachis hypogaea L.) is an important oilseed crop and is cultivated on 23.4 million ha with an annual production of 34.9 million metric tons globally (FAO 2007). In India, groundnut is one of the major oil seed crops with an area of 6.21 million ha, production of 6.74 million tones, and an average yield of $1081 \mathrm{~kg} \mathrm{ha}^{-1}$ (DGR 2011). A large number of insect pests damage this crop, which includes thrips, aphids, Aphis craccivora Koch white grubs, leaf miner, leafhoppers, armyworm, Spodoptera litura Fab., and cotton bollworm, Helicoverpa armigera (Hub.) (Sharma and others 2003). Host plant resistance plays an important role in insect pest management resulting in reduced losses due to the herbivores, less insecticide use, better crops yields, and a safer environment, in addition being cost effective (Sharma and others 2009; Wu and Baldwin 2010). Plants respond to herbivory through various morphological, biochemical and molecular mechanisms to counter/offset the effects of herbivore attack. This form of defense (induced resistance) adversely affects insect feeding, growth, and survival (Howe and Jander 2008; Wu and Baldwin 2010; War and others 2011a). It is a key component of plant defense against insect herbivory (Sethi and others 2009; Chen and others 2009; Karban 2011). Induced resistance in plants is mediated through various defensive enzymes such as, peroxidases (PODs), polyphenol oxidases (PPO), phenyalanine amino lyase (PAL), superoxide dismutase (SOD), ascorbate peroxidase (APX), catalase and secondary metabolites including phenols, condensed tannins etc., and through hydrogen peroxide $\left(\mathrm{H}_{2} \mathrm{O}_{2}\right)$ and malondialdehyde (MDA) (Usha Rani and Jyothsna 2010; Gulsen and others 2010; War and others 2011a; War and others 2012).

Cotton bollworm/legume pod borer, H. armigera is a polyphagous pest, and is widely distributed in Asia, Africa, southern Europe, and Australasia (Sharma and others 2003, 2005). It is a major pest of cereals, grain legumes, cotton, vegetable, and fruit crops, including groundnut (Sharma and others 2005). Cowpea or groundnut aphid, $A$. craccivora is a polyphagous pest, and feeds on a number of crops worldwide (Minja and others 1999; Ahmed and others 2007). It causes severe damage to groundnut by sucking plant sap and by acting as a vector of at least seven viral diseases including groundnut rosette virus and peanut stripe (Padgham and others 1990). Plants respond differentially to insects with different modes of feeding. The chewing insects cause extensive damage to plant 
tissues and induce defense system different from that of the sap sucking insects. The chewing insects (caterpillars) cause an extensive damage to the plant tissue and release a wide range of elicitors that induce specific defense responses that are different from general mechanical damage. On the other hand, aphids with piercing and sucking type of mouth parts use stylets for feeding, and cause minimum physical injury to the plant tissue. They cause serious losses in crops worldwide by draining plant nutrients, injecting plant elicitors, and transmitting pathogenic viruses (Han and others 2009; He and others 2011). Aphids probe into the leaf epidermis cells immediately upon infestation and once probe is initiated; they insert their stylets into the epidermis cell wall and membrane, followed by saliva injection and ingestion of cell wall contents (Tjallingi 2006). The stylet is then inserted further and the insect feeds on phloem (and xylem) sap. Plant defense against herbivory is mediated through both SA and JAdependant pathways (Walling 2000; Moran and others 2002; Zhu-Salzman and others 2004).The present studies were carried out to understand the defensive responses of groundnut genotypes with differential levels of resistance to insect pests with different modes of feeding, and their implications for pest management. The results obtained could serve as the important biochemical markers for plants resistance against insect pests.

\section{Material and methods}

\section{Chemicals}

The chemicals used in this study were of analytical grade. Ethylene diamine tetra aceticacid (EDTA), bovine serum albumin (BSA), guaiacol, polyvinyl pyrolidone (PVP), jasmonic acid, tannic acid, vanillin, linoleic acid, dithiothretol (DTT), disodium hydrogen phosphate, sodium dihydrogen phosphate, nitro-blue tetrazolium salt (NBT), methionine, L-phenylalanine, Glucose, potassium iodide $(\mathrm{KI})$, sodium carbonate $\left(\mathrm{Na}_{2} \mathrm{CO}_{3}\right)$, and vanillin were obtained from Sigma Aldrich, USA. Catechol was obtained from Glaxo Laboratories, Mumbai, India. Coomassie brilliant blue-G250, tris-HCl, and trichloroacetic acid (TCA) were obtained from Sisco Research Lab., Mumbai, India. 2-mercaptoethanol, gallic acid and Folin-Ciocalteau reagent were obtained from Merck, Mumbai, India. Thiobarbituric acid (TBA) and linoleic acid were obtained from HiMedia Pvt. Ltd., Mumbai, India. Ammonium sulphate was obtained from Qualigens Fine Chemicals, Mumbai.

\section{Groundnut plants}


Five groundnut genotypes were grown under greenhouse conditions at the International Crops Research Institute for the Semi-Arid Tropics (ICRISAT), Patancheru, Andhra Pradesh, India, to study their defensive responses towards H. armigera- a chewing type of insect and A. craccivora- a sap sucking type insect. These included: ICGV 86699, ICGV 86031, ICG 2271, ICG 1697 (with moderate to high levels of resistance to insects) and JL 24 (susceptible check) (Sharma and others 2003). The plants were grown in plastic pots (30 cm diameter and $39 \mathrm{~cm}$ deep), filled with a mixture of soil, sand, and farmyard manure (2:1:1). After $10 \mathrm{~d}$ of seedling emergence, only two seedlings of similar growth were retained in each pot. The Desert coolers were used to maintain the temperature at $28 \pm 5^{\circ} \mathrm{C}$ and RH $65 \pm 5 \%$ in greenhouse. Twenty day old plants were infested with ten newly emerged $H$. armigera larvae or 20 nymphs of A. craccivora. Ten replications were maintained for each treatment/genotype in a randomized block design.

\section{Insect infestation}

Newly emerged larvae of $H$. armigera were obtained from the stock culture maintained on chickpea based artificial diet under laboratory conditions $\left(26 \pm 1{ }^{\circ} \mathrm{C} ; 11 \pm 0.5 \mathrm{~h}\right.$ photoperiod and $75 \pm 5 \%$ relative humidity) from the insect rearing laboratory (Armes and others 1992). Ten larvae were gently placed on each 20-day-old plant by using a camel hair brush. The A. craccivora wingless adults were obtained from the culture maintained on groundnut plants in the greenhouse, and 10 aphids were released on each plant using a moistened camel hair brush. The insects were allowed to feed on plants for six days after which the leaves were collected randomly from plants for the biochemical assays.

\section{Enzyme extraction}

Fresh leaves $(0.5 \mathrm{~g})$ were ground in $3 \mathrm{ml}$ of ice cold $0.1 \mathrm{M}$ Tris- $\mathrm{HCl}$ buffer $(\mathrm{pH} 7.5)$ containing $5 \mathrm{mM}$ 2mercaptoethanol, $1 \%$ polyvinylpyrolidone (PVP), $1 \mathrm{mM}$ Dithiothretol (DTT), and $0.5 \mathrm{mM}$ EDTA. The homogenate was centrifuged at $16,000 \times \mathrm{g}$ for $25 \mathrm{~min}$ and the supernatant was used as enzyme source. The supernatant was further processed for partial purification of proteins.

\section{Precipitation of proteins and partial purification}

Proteins were precipitated by ammonium sulphate. To obtain $80 \%$ of saturation, initially $40 \%$ saturation was carried out and finally $80 \%$. Ammonium sulphate $(1.2 \mathrm{~g}$ ) was added to $5 \mathrm{ml}$ of the protein extract to obtain $40 \%$ saturation. 
The solution was kept overnight at $4{ }^{\circ} \mathrm{C}$ and then centrifuged at $12,000 \mathrm{rpm}$ for $30 \mathrm{~min}$. The pellet was collected, and the supernatant was used for further precipitation. For $80 \%$ saturation, ammonium sulphate was added at the rate of $0.28 \mathrm{~g} \mathrm{ml}^{-1}$. The solution was stirred overnight at $4{ }^{\circ} \mathrm{C}$ and salt precipitated proteins were collected after centrifugation at $12,000 \mathrm{rpm}$ for $30 \mathrm{~min}$. The pellets were pooled together and dissolved in buffer $(0.1 \mathrm{M} \mathrm{Tris}-\mathrm{HCl}$

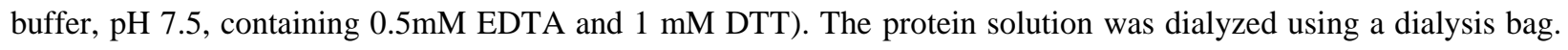
For dialysis, the bag was washed with distilled water, sealed with a plastic clip on one end, and again washed with distilled water. The bag was filled with the precipitated protein sample and sealed on the other end with plastic clip. The dialysis was carried out for $18 \mathrm{~h}$ in the preceding buffer at $4{ }^{\circ} \mathrm{C}$. The buffer was changed after every $3 \mathrm{~h}$.

\section{Enzyme assays}

Peroxidase activity was estimated as per the method of Shannon and others (1966) with slight modification. Enzyme activity was expressed as IU g ${ }^{-1} \mathrm{FW}$. One unit of POD activity was defined as the change in absorbance by 0.1 unit per minute under conditions of assay. For the estimation of PPO activity, method described by Mayer and Harel (1979) was followed with some modifications. Enzyme activity was expressed as IU g ${ }^{-1} \mathrm{FW}$. One unit of PPO was defined as the change in absorbance by 0.1 unit per minute under conditions of assay. The activity of SOD was assayed as described by Beauchamp and Fridovich (1971) with slight modifications. SOD activity was expressed in units (IU g $\mathrm{g}^{-1} \mathrm{FW}$ ), where $1 \mathrm{IU}$ is the change in 0.1 units of absorbance $\min ^{-1}$. LOX activity was measured by following the method of Hildebrand and Hymowitz (1981) with slight modifications. One unit of enzyme activity was defined as the increase in absorbance by 0.01 per min and was expressed as $\mathrm{IU} \mathrm{g}^{-1} \mathrm{FW}$. Catalase activity was determined using the method of Zhang and others (2008). Phenylalanine ammonia lyase was estimated as described by Campos-Vergas and Saltveit (2002) with slight modifications and the activity was expressed as $\mu$ mol Cinnamic acid $\mathrm{min}^{-1} \mathrm{mg}^{-1}$ protein.

\section{Ascorbate peroxidase assay}

To determine the APX activity method of Asada and Takahashi (1987) was followed with slight modifications. Leaf tissue $(0.2 \mathrm{~g})$ was homogenized in a pestle and mortar with $3 \mathrm{ml}$ of $50 \mathrm{mM}$ potassium phosphate buffer $(\mathrm{pH}$ 7.0) containing $1 \mathrm{mM}$ EDTA, $1 \%$ PVP and $1 \mathrm{mM}$ ascorbic acid. After filtering through a double-layered cheese cloth the homogenate centrifuged at $15,000 \mathrm{rpm}$ for $20 \mathrm{~min}$ at $4{ }^{\circ} \mathrm{C}$. The supernatant after precipitation and dialysis was used 
as enzyme source. The reaction mixture $(1 \mathrm{ml})$ contained $50 \mathrm{mM}$ potassium phosphate buffer $(\mathrm{pH} 7.0), 0.5 \mathrm{mM}$ ascorbic acid, $0.1 \mathrm{mM} \mathrm{H} \mathrm{O}_{2}$ and $0.2 \mathrm{ml}$ of partially purified enzyme extract. Decrease in absorbance at $290 \mathrm{~nm}$ due to ascorbate oxidation was measured against the blank and the enzyme activity was expressed as IU $\mathrm{g}^{-1} \mathrm{FW}$, where 1 IU is the change in 0.1 units of absorbance $\min ^{-1}$.

\section{Total phenols, condensed tannins, $\mathrm{H}_{2} \mathrm{O}_{2}, \mathrm{MDA}$ and protein contents}

Phenolic content was estimated as per Zieslin and Ben-Zaken (1993) method with some modifications. Phenolic concentration was determined from standard curve prepared with gallic acid and was expressed as $\mu \mathrm{g}$ Gallic acid

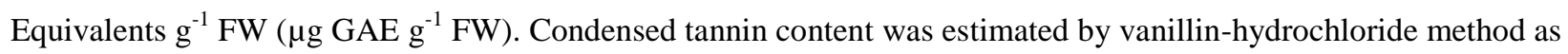
described by Robert (1971) with some modifications. Catechin was used as the standard and the total amount of condensed tannins was expressed as $\mu \mathrm{g}$ catechin equivalents $\mathrm{g}_{-}{ }^{1} \mathrm{FW}\left(\mu \mathrm{g} \mathrm{CE} \mathrm{g}^{-1} \mathrm{FW}\right)$. Hydrogen peroxide content was estimated by the method of Noreen and Ashraf (2009). $\mathrm{H}_{2} \mathrm{O}_{2}$ concentration was determined by using an

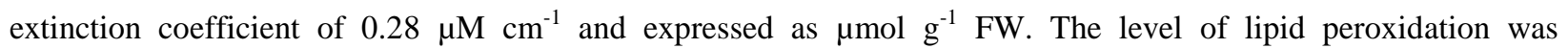
determined in terms of thiobarbituric acid-reactive substances (TBARS) concentration as described by Carmak and Horst (1991) with minor modification. The concentration of TBARS was calculated using the absorption coefficient $155 \mathrm{mmol}^{-1} \mathrm{~cm}^{-1}$ and expressed as $\mu \mathrm{mol} \mathrm{g}{ }^{-1} \mathrm{FW}$. Total protein content was determined according to the method of Lowry and others (1951), using bovine serum albumin as standard.

\section{Plant damage and insect biology}

After six days of infestation, plants were assessed for Helicoverpa damage by visually rating them to a scale 1-9, where, $1=<10 \%$ and $9=>80 \%$ damage (Sharma and others 2003), and A. craccivora damage was evaluated visually on a $1-5$ scoring scale $(1=$ highly resistant, and $5=$ highly susceptible). Number of Helicoverpa larvae and aphids survived were recorded. The Helicoverpa larvae collected were starved for $4 \mathrm{~h}$ and their weights (mg) were recorded using a digital balance (Mettler Toledo, AB304-S).

\section{Statistical analysis}


The data was analyzed by analysis of variance (ANOVA) using SPSS (15.1). Tukey's test was used to separate the means, when the treatment effects were statistically significant $(\mathrm{p} \leq 0.05)$. The differences across the treatments and genotypes were shown by using Dunnett's 't' test.

\section{Results}

\section{POD activity}

Infestation with $H$. armigera and A. craccivora resulted in greater POD activity in all the five groundnut genotypes (Fig. 1). Plants infested with $H$. armigera and A. craccivora showed significantly greater POD activity [ICGV $86699\left(\mathrm{~F}_{(2,8)}=34.3, \mathrm{P}<0.001\right)$, ICGV $86031\left(\mathrm{~F}_{(2,8)}=25.4, \mathrm{P}<0.01\right)$, ICG $2271\left(\mathrm{~F}_{(2,8)}=28.2, \mathrm{P}<0.05\right), \mathrm{ICG} 1697$ $\left(\mathrm{F}_{(2,8)}=19.3, \mathrm{P}<0.01\right)$, and JL $\left.24\left(\mathrm{~F}_{(2,8)}=25.9, \mathrm{P}<0.05\right)\right]$ as compared to the uninfested control plants. Across the genotypes, ICGV 86699 showed a strong induction of POD activity in all the plants infested with insects $[H$. armigera $\left(\mathrm{F}_{(4,14)}=45.4, \mathrm{P}<0.01\right) ;$ A. craccivora $\left(\mathrm{F}_{(4,14)}=23.5, \mathrm{P}<0.05\right)$, as well as the uninfested control plants $\left.\left(\mathrm{F}_{(4,14)}=12.3, \mathrm{P}<0.05\right)\right]$ than rest of the genotypes. JL 24 also exhibited increased POD activity following insect infestation, but the activity was lower than in the insect resistant genotypes. The POD activity was greater in the uninfested insect-resistant genotypes than in the susceptible check, JL 24.

\section{PPO activity}

Greater induction in PPO activity was observed in H. armigera and A. craccivora infested plants of all the groundnut genotypes [ICGV $86699\left(\mathrm{~F}_{(2,8)}=45.3, \mathrm{P}<0.001\right), \mathrm{ICGV} 86031\left(\mathrm{~F}_{(2,8)}=89.4, \mathrm{P}<0.001\right), \mathrm{ICG} 2271\left(\mathrm{~F}_{(2,8)}\right.$ $=32.3, \mathrm{P}<0.05)$, ICG $1697\left(\mathrm{~F}_{(2,8)}=19.5, \mathrm{P}<0.01\right)$, and JL $24\left(\mathrm{~F}_{(2,8)}=15.9, \mathrm{P}<0.05\right)$ than in the uninfested control plants (Fig. 2). ICGV 86699 and ICGV 86031 plants infested with H. armigera showed significantly greater PPO activity $\left(\mathrm{F}_{(4,14)}=78.4,67.2\right.$, respectively for ICGV 86699 and ICGV 86031, P < 0.001$)$ than that of ICG 2271 , ICG 1697 and JL 24. Insect resistant genotypes had higher PPO activity $\left(\mathrm{F}_{(4,14)}=23.8, \mathrm{P}<0.05\right)$ in A. craccivora infested plants than that of JL 24 .

\section{PAL activity}

A strong induction of PAL activity was observed in response to insect infestation (Fig. 3). Both H. armigera and A. craccivora infested plants had greater PAL activity [ICGV $86699\left(\mathrm{~F}_{(2,8)}=34.5, \mathrm{P}<0.001\right), \mathrm{ICG} 2271\left(\mathrm{~F}_{(2,8)}=12.6 .7\right.$, 
$\mathrm{P}<0.001)$, ICG $1697\left(\mathrm{~F}_{(2,8)}=18.9, \mathrm{P}<0.05\right)$, and JL $\left.24\left(\mathrm{~F}_{(2,8)}=11.5, \mathrm{P}<0.05\right)\right]$ than the uninfested control plants. However, in ICGV 86031, H. armigera infestation elicited significantly greater PAL activity $\left(\mathrm{F}_{(2,8)}=33.3, \mathrm{P}<0.01\right)$ than A. craccivora infested and uninfested control plants. ICGV 86699 and ICGV 86031 plants infested with $H$. armigera exhibited greater PAL activity $\left(\mathrm{F}_{(4,14)}=23.2, \mathrm{P}<0.05\right)$ than the other genotypes. The PAL activity in $A$. craccivora infested plants of ICGV 86699, ICG 2271, and ICG 1697 was significantly higher $\left(\mathrm{F}_{(4,14)}=18.6\right.$, P < 0.05) than that of the susceptible check. JL 24. The constitutive levels of PAL in insect-resistant genotypes were significantly greater than in the susceptible genotype, JL 24.

\section{CAT activity}

Insect infestation resulted in increased activity of CAT (Fig 4). Plants infested with $H$. armigera and A. craccivora had significantly greater CAT activities $\left(\mathrm{F}_{(2,8)}=12.2,18.9\right.$, 17.7, and 9.5, respectively for ICGV 86699, ICGV 86031, ICG 2271, and ICG 1697, P < 0.05) than the uninfested control plants. ICGV 86699 and ICGV 86031 showed significantly greater CAT activity in plants infested with $H$. armigera $\left(\mathrm{F}_{(2,8)}=23.6, \mathrm{P}<0.05\right)$ and $A$. craccivora $\left(\mathrm{F}_{(2,8)}=14.2, \mathrm{P}<0.05\right)$ infested plants than in ICG 2271, ICG 1697, and JL 24. Constitutive CAT activity was higher in insect-resistant genotypes than in the susceptible check, JL 24.

\section{SOD activity}

Both $H$. armigera and A. craccivora infestation increased the SOD activity in all the groundnut genotypes (Fig. 5). The induction was significantly greater in H. armigera infested plants in ICGV $86699\left(\mathrm{~F}_{(2,8)}=68.7, \mathrm{P}<0.01\right)$ and ICG $2271\left(\mathrm{~F}_{(2,8)}=23.5, \mathrm{P}<0.05\right)$ than A. craccivora infested, and uninfested control plants. There was no significant difference in SOD activity between $H$. armigera and A. craccivora infested plants in ICGV 86031, ICG 1697, and JL 24. Constitutive levels of SOD activity were lower in JL 24 than in the insect-resistant genotypes. ICGV 86699 and ICG 1697 had greater SOD activity in both H. armigera $\left(\mathrm{F}_{(4,14)}=98.1, \mathrm{P}<0.001\right)$ and $A$. craccivora $\left(\mathrm{F}_{(4,14)}=34.7, \mathrm{P}<0.05\right)$ infested plants than that of ICGV 86031, ICG 2271, and JL 24. .

\section{APX activity}

The APX activities were significantly greater in $H$. armigera infested plants of ICGV $86699\left(\mathrm{~F}_{(2,8)}=43.8, \mathrm{P}<0.01\right)$, ICGV $86031\left(\mathrm{~F}_{(2,8)}=27.8, \mathrm{P}<0.01\right)$, and ICG $1697\left(\mathrm{~F}_{(2,8)}=12.3, \mathrm{P}<0.05\right)$ than those infested with A. craccivora 
and the uninfested control plants (Fig. 6). The H. armigera and A. craccivora infested plants of ICG 2271 and JL 24 had greater APX activities (both, $\mathrm{P}>0.05)$ than their uninfested control plants $(\mathrm{P}<0.05)$. Across the genotypes, $H$. armigera infested plants of ICGV 86699, ICGV 86031 and ICG 1697 showed significantly greater APX activity $\left(\mathrm{F}_{(4,14)}=32.4, \mathrm{P}<0.05\right)$ than that of ICG 2271, and JL 24. ICGV 86699 plants infested with A. craccivora had higher APX activities $\left(\mathrm{F}_{(4,14)}=19.1, \mathrm{P}<0.001\right)$ than the A. craccivora infested plants of ICGV 86031, ICG 2271, ICG 1697, and JL 24. Constitutive levels of APX were significantly higher than that in ICGV 86031, ICG 2271 followed by ICGV 86699 and ICG 1697 and JL 24.

\section{LOX activity}

Insect infestation resulted in increased levels of LOX in all the genotypes (Fig. 7). The induction was significantly greater in plants infested with $H$. armigera and A. craccivora in resistant genotypes [ICGV $86699\left(\mathrm{~F}_{(2,8)}=6.8, \mathrm{P}<\right.$ 0.01), ICGV $86031\left(\mathrm{~F}_{(2,8)}=8.9, \mathrm{P}<0.05\right)$, and ICG $1697\left(\mathrm{~F}_{(2,8)}=11.6, \mathrm{P}<0.05\right)$ than the uninfested control plants. In ICGV 2271, LOX activity in $H$. armigera infested plants were significantly greater $\left(\mathrm{F}_{(2,8)}=18.5, \mathrm{P}<0.01\right)$ than those infested with A. craccivora and the uninfested control plants. Insect- resistant ones showed greater increase in LOX activity in plants infested with $H$. armigera $\left(\mathrm{F}_{(4,14)}=9.1, \mathrm{P}<0.05\right)$, and A. craccivora $\left(\mathrm{F}_{(4,14)}=5.2, \mathrm{P}<0.05\right)$ than in JL 24.

\section{Total phenols}

Insect damage resulted in a tremendous increase in the amounts of phenolic compounds than the uninfested control plants (Fig. 8). Increase in phenolic content was significantly greater in $H$. armigera infested plants than those infested with A. craccivora $\left(\mathrm{F}_{(2,28)}=39.4,16.8,28.1\right.$, and 13.6, respectively for ICGV 86699, ICGV 86031, ICG 2271, and ICG 1697, all P < 0.001). No significant difference was observed between H. armigera and A. craccivora infested plants of the susceptible check, JL 24 (P > 0.05). Across the genotypes, the insect infested plants of ICGV 86699 showed higher phenolic content $\left[\right.$ H. armigera infested $\left(\mathrm{F}_{(4,14)}=16.2, \mathrm{P}<0.01\right.$, and A. craccivora infested $\left.\left(\mathrm{F}_{(4,14)}=14.3, \mathrm{P}<0.01\right)\right]$ than ICGV 86031, ICG 2271, ICG 1697, and JL 24. Constitutive levels of phenolic compounds were similar among the resistant genotypes, but significantly higher $\left(\mathrm{F}_{(4,14)}=9.3, \mathrm{P}<0.05\right)$ than the susceptible genotype, JL 24. 


\section{Condensed tannins}

The $H$. armigera infested plants had greater amounts of tannins in the insect-resistant genotypes $\left(\mathrm{F}_{(2,28)}=13.7,21.1\right.$, 7.4, and 11.6, respectively for ICGV 86699, ICGV 86031, ICG 2271, ICG 1697, all P < 0.001) than those infested with A. craccivora and the uninfested control plants (Fig. 9). Insect-resistant genotypes, in general, had significantly higher tannin content $\left[H\right.$. armigera infested $\left(\mathrm{F}_{(4,14)}=11.4, \mathrm{P}<0.01\right.$, A. craccivora infested $\left(\mathrm{F}_{(4,14)}=18.3, \mathrm{P}<0.05\right)$ and the uninfested controls $\left.\left(\mathrm{F}_{(4,14)}=21.4, \mathrm{P}<0.05\right)\right]$ across the genotypes.

\section{$\mathrm{H}_{2} \mathrm{O}_{2}$ content}

Greater amounts of $\mathrm{H}_{2} \mathrm{O}_{2}$ were observed in insect-infested plants of all the genotypes (Fig. 10). $\mathrm{H}_{2} \mathrm{O}_{2}$ content was significantly greater in $H$. armigera infested plants of ICGV 86031, ICG 1697 and JL 24 than the A. craccivora infested and uninfested control plants $\left(\mathrm{F}_{(2,28)}=11.2,14.4,23.1\right.$, respectively for ICGV 86031, ICG 1697, and JL 24, all $\mathrm{P}<0.05)$. ICGV 86699 and ICG 2271 had greater $\mathrm{H}_{2} \mathrm{O}_{2}$ content in $H$. armigera and $A$. craccivora infested plants than the uninfested controls $\left(\mathrm{F}_{(2,28)}=17.5\right.$ and 9.6, respectively for ICGV 86699 and ICG 2271, all P<0.01). Similarly greater induction of $\mathrm{H}_{2} \mathrm{O}_{2}$ was recorded in A. craccivora infested plants of resistant genotypes $\left(\mathrm{F}_{(4,14)}=\right.$ 13.3, $\mathrm{P}<0.05)$ than those of the susceptible check, JL 24. Constitutive levels of $\mathrm{H}_{2} \mathrm{O}_{2}$ were greater in the insectresistant genotypes than in JL 24.

\section{MDA content}

A significant increase in MDA content was observed in insect-infested plants as compared to the uninfested controls (Fig. 11). Greater MDA content was observed in $H$. armigera infested plants $\left(\mathrm{F}_{(2,28)}=12.5,17.3\right.$, and 45.5 , respectively for ICGV 86031, ICG 2271, and JL 24, all P < 0.01) than in A. craccivora infested, and the uninfested control plants. JL 24 had greater amounts of MDA in $H$. armigera infested plants $\left(\mathrm{F}_{(4,14)}=78.3, \mathrm{P}<0.05\right)$ than that of ICGV 86699, ICGV 86031, ICG 2271, and ICG 1697. No significant differences were recorded in MDA content of $A$. craccivora infested plants among the genotypes tested.

\section{Protein content}

Significant increase in protein content was observed in insect infested plants as compared to the control plants (Fig. 12). There were no significant differences between the plants infested with $H$. armigera and $A$. craccivora. Insect- 
resistant genotypes had higher protein content in the insect infested plants $\left[\right.$ H. armigera infested $\left(\mathrm{F}_{(4,14)}=24.3, \mathrm{P}<\right.$ 0.01, A. craccivora infested $\left.\left(\mathrm{F}_{(4,14)}=19.4, \mathrm{P}<0.05\right)\right]$ than the susceptible genotype, JL 24 .

\section{Plant damage and insect biology}

Greater leaf damage by $H$. armigera was observed in susceptible check, JL 24 as compared to that on ICGV 86699, ICGV 86031, ICG 2271 and ICG 1697. After 6 DAI, leaf damage rating by H. armigera ranged from 2.8 in ICGV 86699 to 7.5 in JL 24 (Table 1). Survival of H. armigera larvae was significantly lower in resistant genotypes ICGV 86699 (33.5\%), ICGV 86031 (39.4\%), ICG 2271 (45.6\%) and ICG 1697 (48.3\%) than on the susceptible check, JL $24(77.5 \%)$. The genotypes exhibiting low susceptibility to $H$. armigera were also less susceptible to the aphid, $A$. craccivora, and least aphid damage was recorded in ICGV 1697 (DR 2.0) as compared to 4.2 in the susceptible check, JL 24. Similar trend was observed in terms of numbers of aphids. ICG 1697 had the least number of aphids (19 per plant), while the susceptible check, JL 24 had the highest (56.5) number of aphids per plant. Weights of $H$. armigera larvae were significantly lower (55.5 - 68.9 mg/5 larvae) on ICGV 86699, ICGV 86031, ICG 2271, and ICG 1697 than those fed on the susceptible check, JL 24 (95.5 mg/5 larvae).

\section{Discussion}

The evolutionary race between plants and insects has resulted in the development of an elegant defense system in plants that recognizes the non-self molecules or signals from the damaged plant parts/cells or the insect regurgitants and in turn activates the plant defense response against the herbivores (Howe and Jander 2008; Karban 2011; Smith and Clement 2012). When damaged by herbivorous insects, plants produce increased amounts of antinutritive and toxic proteins and secondary metabolites that interfere with oviposition, feeding, digestion and absorption of essential nutrients by the insects (Howe and Jander 2008; He and others 2011; Wu and Baldwin 2010; Smith and Clement 2012). The successful defense of plants against the biotic stresses depends on their ability to quickly perceive the incoming stimuli, decode it, and build a strong morphological, physiological, and/or biochemical shield against the invaders. The oxidative state of the host plants, an important component of host plant resistance to insects results in the production of ROS and toxic secondary metabolites (Howe and Jander 2008; Zhao and others 2009; Wu and Baldwin 2010; He and others 2011). Different defensive systems are activated in response to different modes of feeding by the insects. 
Antioxidative enzymes such as POD, PPO, LOX, SOD, PAL, and CAT are induced in plants in response to herbivory (Felton and others 1994; Zhao and others 2009; He and others 2011). Infestation of groundnut plants by H. armigera and A. craccivora resulted in a strong induction of defensive enzymes including POD, PPO, PAL, CAT, SOD, APX, and LOX in all the genotypes, however, the strength of induction varied across insects and genotypes. There were no significant differences in the activities of POD, PAL and CAT in groundnut genotypes infested by $H$. armigera and A. craccivora, except in ICGV 86699 and ICGV 86031, where the H. armigera infested plants exhibited greater POD and PPO activities, respectively, than the A. craccivora infested plants. In the susceptible check, JL 24, the $H$. armigera infested plants resulted in greater induction of CAT activity than $A$. craccivora infested plants, and the uninfested control plants. The H. armigera infested plants of ICGV 86699, ICGV 86031, and ICG 2271 exhibited greater PPO activity as compared to those infested by A. craccivora.

In general, greater SOD activity was observed in insect infested plants than the uninfested control plants across the genotypes. However, ICGV 86699 and ICG 2271 showed significantly greater SOD activity in H. armigera infested plants than A. craccivora infested and the uninfested control plants. Overall, the insect resistant genotypes exhibited greater CAT activity in $H$. armigera and A. craccivora infested plants than the uninfested control plants. Greater APX activity was observed in $H$. armigera infested plants than $A$. craccivora infested plants, and the uninfested control plants, except in ICG 2271 and JL 24. The LOX activity increased significantly in both H. armigera and A. craccivora infested plants in all the genotypes, and there were no significant differences in the levels of LOX activity between the two treatments in all the genotypes, except ICG 2271. Overall, the insect-resistant genotypes exhibited greater induction of LOX activity than the susceptible check, JL 24.

The enzymes POD, PPO, PAL, CAT, SOD, APX, and LOX play a great role in plant defense against different stresses, including insect herbivory (Bhonwong and others 2009; Zhao and others 2009; Chen and others 2009; Gulsen and others 2010; Usha Rani and Jyothsna 2010, He and others 2011; War and others 2011a,b,c). The role of POD in production of semiquinone free radicals and subsequent formation of quinones has been attributed to its direct post ingestive toxicity against insects (Zhu-Salzman and others 2008; Barbehenn and others 2010). In addition, it also mediates the oxidation of hydroxylcinnamyl alcohols into free radical intermediates, oxidation of phenols, cross-linking of polysaccharides and monomers, lignifications, and suberization (Zhang and others 2008; Chen and others 2009), which in turn lead to the production of anti-nutritive compounds (Gulsen and others 2010; 
He and others 2011). Induction of POD activity was greater in the insect-resistant genotypes than the susceptible check, JL 24. The PPO plays an important role in plant defense against insect herbivory as an antinutritional enzyme, and reduces the food quality (Mahanil and others 2008; Bhonwong and others 2009). It oxidizes phenols to highly reactive and toxic quinines that interact with the nucleophilic side chain of amino acids, leading to crosslinking of proteins, and thereby, reducing their availability to insect pests (Zhang and others 2008; Bhonwong and others 2009). In addition to their role in digestibility and palatability of plant tissues, melanin formation by PPOs increases the cell wall resistance to insects and pathogens (Zhao and others 2009).

The de novo synthesis and increased activity of PAL is an initial plant defensive response to insect damage (Campos-Vargas and Saltveit 2002), and leads to accumulation of phenolic compounds in plants that are sequestered in cell vacuole (Zhao and others 2009), and forms toxic compounds upon oxidation (Bhonwong and others 2009). A negative correlation has been observed between PAL activity and growth and development of insect pests (Sethi and others 2009). The SOD acts as the first line of defense by catalyzing the dismutation of superoxide into oxygen and $\mathrm{H}_{2} \mathrm{O}_{2}$ (Raychaudhuri and Deng 2000). It scavenges the toxic free radicals produced in plants on account of stresses, including herbivory (Khattab and Khattab 2005; Usha Rani and Jyothsna 2010). CAT is an important component of the oxygen-scavenging systems, scavenges the toxic and unstable ROS and converts them into less toxic and more stable components such as $\mathrm{O}_{2}$ and water (Khattab and Khattab 2005). Increased CAT activity in plants increases cell wall resistance, and also acts as a signal for the induction of defensive genes (Chen and others 1993). Higher levels of APX activity decrease the availability of ascorbate in plant tissues, which in turn reduces the insect growth and development (Barbehenn and others 2005). In addition, non-availability of ascorbate in insect midgut increases the oxidative stress that leads to the generation of highly unstable ROS, including semiquinone, peroxides, and hydroxyl radicals (Barbehenn and others 2005). APX also reduces excessive $\mathrm{H}_{2} \mathrm{O}_{2}$ to water, and oxidizes phenolic compounds to quinones, which inhibit insect feeding (Felton and others 1994; Barbehenn and others 2005). LOX catalyze hydroperoxidation of polyunsaturated fatty acids resulting in the formation of fatty acid hydroperoxides, which are degraded to unstable and highly reactive aldehydes, $\gamma$-ketols, epoxides (Bruinsma and others 2009). These interact with proteins, and forms protein-protein cross linking and also cause amino acid damage (Maffei and others 2007). Lipid peroxidation end products act as insect repellents (Bruinsma and others 2009), which are directly toxic to insect pests (Maffei and others 2007; Bhonwong and others 2009). Nicotiana attenuata (Torr. ex Wat.) plants 
deficient in LOX have been found to be susceptible to Manduca sexta (L.) (Rayapuram and Baldwin 2007). Greater induction of plant defensive enzymes in groundnut plants in response to H. armigera infestation could be attributed to the more tissue damage by the chewing insect.

Amounts of total phenols and condensed tannins were greater in H. armigera infested plants than those infested by A. craccivora in insect resistant genotypes. Increase in amounts of phenols and condensed tannins were higher in insect-resistant genotypes than in the susceptible check, JL 24. This could be ascribed to the extensive tissue damage by the chewing insects. Phenolic compounds induced in plants are either directly toxic to insects (Walling 2000; Bhonwong and others 2009) or mediate the signaling of various transduction pathways, which in turn, produce toxic secondary metabolites and activates the defensive enzymes (Walling 2000; Maffei and others 2007; Bhonwong and others 2009). Quinones formed by oxidation of phenols bind covalently to leaf proteins, and inhibit protein digestion in herbivores (Bhonwong and others 2009). Tannins have been reported to reduce the growth and survivorship in many insect pests (Grayer and others 1992; Bernards and Bastrup-Spohr 2008; Sharma and others 2009). They precipitate proteins nonspecifically (including the digestive enzymes of herbivores) by hydrogen bonding or covalent bonding of protein $-\mathrm{NH}_{2}$ groups, thereby, reducing the nitrogen mineralization and/or digestion in herbivore midgut (Bernards and Bastrup-Spohr 2008). Sharma and others (2009) reported higher quantity of polyphenols and condensed tannins in insect resistant genotypes of pigeonpea that are resistant to H. armigera.

Greater amounts of $\mathrm{H}_{2} \mathrm{O}_{2}$ were recorded in insect infested plants, and the insect-resistant genotypes responded strongly than the susceptible check, JL 24. The $\mathrm{H}_{2} \mathrm{O}_{2}$ acts directly as a toxicant to the insects or as a secondary messenger, where it serves as an important component of intra- and intercellular signal transduction pathways, which in turn lead to the formation of various defensive proteins (Howe and Jander 2008; Maffei and others 2007; Torres 2010). The $\mathrm{H}_{2} \mathrm{O}_{2}$ induces various defense signaling pathways in plants in response to insect attack (Meffai and others 2007; Torres 2010). Induction of $\mathrm{H}_{2} \mathrm{O}_{2}$ in plants in response to herbivory could be highly advantageous, since the timing of induction of defensive responses is an important factor for defending the plants against subsequent insect and pathogen invasion (Torres and others 2010; Barbehenn and others 2010; He and others 2011). Increase in MDA content was observed in plants infested with insect pests; however, H. armigera infestation showed greater induction than the A. craccivora infested plants. An important lipid oxidation, MDA is involved in singnaling the plant defense against a variety of stresses (Huang and others 2007). Lipid peroxidation stimulates the 
green leaf volatile emission in plants in response to herbivory that attract the natural enemies of the herbivores (Arimura and others 2009).

The present findings indicated that feeding by $H$. armigera and A. craccivora resulted in an increase in protein content. Increase in protein concentration due to $H$. armigera and A. craccivora feeding might be partly due to the increase in antioxidative enzyme activities after herbivory. Protein based compounds mediate a wide ranging defense responses in plants. On insect infestation, the production of defensive protein based compounds following insect infestation, including enzymes, are one the important strategies of plant defense ( $\mathrm{Ni}$ and others 2001; Chen and others 2009). However, there were considerable differences in protein content in $\mathrm{H}$. armigera and A. craccivora infested plants, which might be due to the extent of the stress caused by the insects due to different modes of feeding.

Genotypes with insect resistance affect both growth and development of herbivores (Sharma and others 2003). Insect-resistant genotypes suffered lower leaf damage by $H$. armigera larvae. The $H$. armigera larvae fed on resistant genotypes exhibited lower larval survival and weights than those larvae fed on the susceptible check, JL 24. Rate of increase of A. craccivora population was significantly lower on the insect-resistant genotypes than that on the susceptible check, JL 24. Amongst these, ICG 1697 suffered the lowest aphid damage; because of a dense covering of trichomes on the leaves (War and others unpublished data). Furthermore, reduced plant damage and high larval mortality on insect-resistant genotypes could be due to increased enzyme activities (Mahanil and others 2008; Bhonwong and others 2009; Usha Rani and Jyothsna 2010; Gulsen and others 2010; He and others 2011), and greater amounts of secondary metabolites (Sharma and others 2009; Bhonwong and others 2009; Chen and others 2009; Usha Rani and Jyothsna 2010; War and others 2011a,b).

\section{Conclusions}

Plant damage by $H$. armigera feeding induced strong response than the sucking pest A. craccivora. Although many reports have suggested that plants respond differently to chewing and sap sucking insects, our results revealed that groundnut plants respond in a similar manner to both the chewing and sap sucking insects, although the degrees of the induced response varied among the genotypes and the insects. Lower induction of plant defensive compounds by A. craccivora infestation as compared to $H$. armigera might be due to the greater tissue damage in leaves by $H$. 
armigera larvae. However, defensive responses induced by A. craccivora could be due to the damage caused due to stylet probing, and the elicitors in the oral secretions released on the leaf. There is a need for in-depth studies on plant response to arthropod herbivores to gain a better understanding of the signal transduction, co-evolution between plants and insects, and the mechanisms of plant resistance to insects to use this information for crop protection and sustainable crop production. 


\section{References}

Ahmed AAI, Abd El-Salam AME, El-Hawary FMA (2007) Persistence and biological activity of mint and garlic oils against the cowpea aphid, Aphis craccivora Koch.( Homoptera: Aphididae). Egypt J Biol Pest Cont $17(1): 7-11$

Arimura G, Matsui K, Takabayashi J (2009) Chemical and molecular ecology of herbivore-induced plant volatiles: proximate factors and their ultimate functions. Plant Cell Physiol 50 (5):911-923

Asada K, Takahashi M (1987) Production and scavenging of active oxygen in photosynthesis. In: Kyle DJ, Osmond CB, Arntzen CJ (eds), Photoinhibition. Elsevier, Amsterdam. pp 227-287

Barbehenn R, Dukatz C, Holt C, Reese A, Martiskainen O, Salminen JP, Yip L, Tran L, Constable CP (2010) Feeding on poplar leaves by caterpillars potentiates foliar peroxidase action in their guts and increase plant resistance. Oecologia 164: 993-1004

Barbehenn RV, Cheek S, Gasperut A, Lister E, Maben R (2005) Phenolic compounds in red oak and sugar maple leaves have prooxidant activities in the midguts of Malacosoma disstria and Orgyia leucostigma caterpillars. J Chem Ecol 31:969-988

Beauchamp C, Fridovich I (1971) Superoxide dismutase: improve assay and an assay applicable to acrylamide gels. Anal Biochem 44:276-287

Bernards MA, Bastrup-Spohr L (2008) Phenylpropanoid metabolism induced by wounding and insect herbivory. In: Induced Plant Resistance to Herbivory (ed. Schaller A.). Springer Verlag, Berlin, pp 189-211

Bhonwong A, Stout MJ, Attajarusit J, Tantasawat P (2009) Defensive role of tomato Polyphenol oxidase against cotton bollworm (Helicoverpa armigera) and Beet armyworm (Spodoptera exigua). J Chem Ecol 35:2838 
Bruinsma M, Posthumus MA, Mumm R, Mueller MJ, van Loon JJA, Dicke M (2009) Jasmonic acid-3 induced volatiles of Brassica oleracea attracts parasitoids: Effects of time and dose, and comparison with induction by herbivores. J Exp Bot 60:2575-2587

Campos-Vargas R, Saltveit ME (2002) Involvement of putative chemical wound signals in the induction of phenolic metabolism in wounded lettuce. Physiol Plant 114:73-84

Carmak I, Horst JH (1991) Effects of aluminum on lipid peroxidation, superoxide dismutase, catalase and peroxidase activities in root tips of soybean. (Glycine max). Physiol Plant 83:463-468

Chapman AD (2006) Numbers of living species in Australia and the World. Canberra: Australian Biological Resources Study pp. 60 pp. ISBN 978-0-642-56850-2

Chen Y, Ni X, Buntin GD (2009) Physiological, nutritional and biochemical bases of corn resistance to foliagefeeding fall Armyworm. J Chem Ecol 35:297-306

Chen Z, Silva H, Klessig DF(1993) Active oxygen species in the induction of plant systemic acquired resistance by salicylic acid. Science 262:1883-1886

Directorate of Groundnut Research (DGR) (2011) Kharif groundnut workshop, Maharana Pratap University of Agriculture and Technology, Udaipur, India, April 22-24, 2011. Annual report, 2010; pp. i-viii

Felton GW, Bi JL, Summers CB, Mueller AJ, Duffey SS (1994) Potential role of lipoxygenases in defense against insect herbivory. J Chem Ecol 20:651-66

Food and Agriculture Organization (2007) http://www/FAO.ORG. FAOSTAT database 2007

Grayer RJ, Kimmins FM, Padgham DE, Harborne JB, Ranga Rao DV (1992) Condensed tannin levels and resistance in groundnuts (Arachis hypogoea (L.) against Aphis craccivora (Koch). Phytochemstry 31: 3795-3799 
Gulsen O, Eickhoff T, Heng-Moss T, Shearman R, Baxendale F, Sarath G, Lee D (2010) Characterization of peroxidase changes in resistant and susceptible warm-season turf grasses challenged by Blissus occiduus. Arthropod-plant Interact 4:45-55

Han Y, Wang Y, Bi JL, Yang XQ, Huang Y, Zhao X, Hu Y, Cai QN (2009)Constitutive and induced resistance in aphid-resistant and aphid-susceptible cultivars of wheat. J Chem Ecol 35:176-182

He J, Chen F, Chen S, Lv G, Deng Y, Fang Z, Guan Z, He C (2011) Chrysanthemum leaf epidermal surface morphology and antioxidant and defense enzyme activity in response to aphid infestation. J Plant Physiol doi:10.1016/j.jplph.2010.10.2009

Hildebrand D, Hymowitz T (1983) Lipoxygenase Activities in Developing and Germinating Soybean Seeds with and Without Lipoxygenase-1. Bot Gaz 144:212-216

Howe GA, Jander G (2008) Plant immunity to herbivores. Ann Rev Plant Biol 59:41-66

Huang W, Zhikuan J, Qingfang H (2007) Effects of herbivore stress by Aphis medicaginis Koch on the melondialdehyde contents and activities of protective enzymes in different alfalfa varieties. Acta Ecol Sinica 27(6):2177-2183

Karban R (2011) The ecology and evolution of induced resistance against herbivores. Func Ecol 25:339-347

Khattab H, Khattab M (2005) Responses of Eucalypt trees to the insect feeding (Gall-forming psyllid). Int J Agri Biol 7 (6): DOI: 1560-8530/2005/07-6-979-984

Lowery OH, Rosebrough NI, Farr AL, Randall RJ (1951) Protein measurement with the Folin phenol reagent. J Biol Chem 193:265-275

Maffei ME, Mithofer A, Boland W (2007) Insects feeding on plants: Rapid signals and responses preceding the induction of phytochemical release. Phytochemistry 68:2946-2959 
Mahanil S, Attajarusit J, Stout MJ, Thipyapong P (2008) Overexpression of tomato polyphenol oxidase increases resistance to common cutworm. Plant Sci 174:456-466

Mayer AM, Harel E (1979) Polyphenol oxidases in plant. Phytochemistry 18:193-215

Minja EM, van der Merwe PJA, Kimmins FM, Subrahmanyam P (1999) Screening Groundnut breeding lines for resistance to aphids, Aphis craccivora Koch. Inter Arachis Newslett 19:21-23

Moran PJ, Cheng YF, Cassell JL, Thompson GA (2002) Gene expression profiling of Arabidopsis thaliana in compatible plant-aphid interactions. Arch Insect Biochem Physiol 51:182-203

Ni X, Quisenberry SS, Heng-Moss T, Markwell J, Sarath G, Klucas R, Baxendale F (2001) Oxidative responses of resistant and susceptible cereal leaves to symptomatic and non-symptomatic cereal aphid (Hemiptera: Aphididae) feeding. J Econ Entomol 94:743-751

Noreen Z, Ashraf M (2009) Change in antioxidant enzymes and some key metabolites in some genetically diverse cultivars of radish (Raphanus sativus L.) Environ Exp Bot 67:395-402

Padgham DE, Kimmins FM, Ranga Rao GV (1990) Resistance in groundnut (Arachis hypogaea L.) to Aphis craccivora (Koch). Ann App Biol 117:285-294

Rayapuram C, Baldwin IT (2007) Increased SA in NPR1-silenced plants antagonizes JA and JA-41 dependent direct and indirect defenses in herbivore-attacked Nicotiana attenuata in nature. Plant J 52:700-715

Raychaudhuri S, Deng XW (2000) The role of superoxide dismutase in combating stress in higher plants. Bot Rev $66: 89-98$

Robert EB (1971) Method for estimation of tannin in grain sorghum. Agro J 63:511 
Sethi A, McAuslane HJ, Rathinasabapathi B, Nuessly GS, Nagata RT (2009) Enzyme induction as a possible mechanism for latex-mediated insect resistance in romaine lettuce. J Chem Ecol 35:190-200

Shannon LM, Kay E, Lew JY (1966) Peroxidase isozymes from horse radish roots. Isolation and physical properties. J Biol Chem 241:2166-2172

Sharma HC, Pampathy G, Dhillon MK, Ridsdill-Smith JT (2005) Detached leaf assay to screen for host plant resistance to Helicoverpa armigera. J Econ Entomol 98(2):568-576

Sharma HC, Pampathy G, Dwivedi SL, Reddy LJ (2003) Mechanism and diversity of resistance to insect pests in wild relatives of groundnut. J Econ Entomol 96 (6):1886-1897

Sharma HC, Sujana G, Rao DM (2009) Morphological and chemical components of resistance to pod borer, Helicoverpa armigera in wild relatives of pigeonpea. Arthropod-Plant Interact 3(3):151-161

Smith CM, Clement SL (2012) Molecular bases of plant resistance to arthropods. Annu Rev Entomol 57:309-28

Tjallingi W (2006) Salivary secretions by aphids interacting with proteins of phloem wound responses. J Exp Bot $57: 739-745$

Torres MA (2010) ROS in biotic interactions. Physiol Plant 138:414-429

Usha Rani P, Jyothsna Y (2010) Biochemical and enzymatic changes in rice as a mechanism of defense. Acta Physiol Plant 32:695-701

Walling LL (2000) The myriad plant responses to herbivores. J Plant Growth Regul 19:195-216

War AR, Paulraj MG, War MY, Ignacimuthu S (2011a) Jasmonic acid- mediated induced resistance in groundnut (Arachis hypogaea L.) against Helicoverpa armigera (Hubner) (Lepidoptera: Noctuidae). J Plant Growth Regul 30:512-523 
War AR, Paulraj MG, War MY, Ignacimuthu S (2011b) Herbivore- and Elicitor- Induced Resistance in Groundnut to Asian armyworm, Spodoptera litura (Fab.) (Lepidoptera: Noctuidae). Plant Signal Behav 6 (11):17691777

War AR, Paulraj MG., War MY, Ignacimuthu S (2012) Herbivore induced resistance in different Groundnut germplasm lines to Asian armyworm, Spodoptera litura (Fab.) (Lepidoptera: Noctuidae). Acta Physiol Plant 34: 343-352

Wu J, Baldwin IT (2010) New insights into plant responses to attack from insect herbivores. Annu Rev Genet 44:124

Zhang SZ, Hau BZ, Zhang F (2008) Induction of the activities of antioxidative enzymes and the levels of malondialdehyde in cucumber seedlings as a consequence of Bemisia tabaci (Hemiptera: Aleyrodidae) infestation. Arthropod-Plant Interact 2:209-213

Zhao LY, Chen JL, Cheng DF, Sun JR, Liu Y, Tian Z (2009) Biochemical and molecular characterizations of Sitobion avenae - induced wheat defense responses. Crop Prot 28:435-442

Zhu- Salzman K, Luthe DS, Felton GW (2008) Arthropod-induced proteins: Broad spectrum defenses against multiple herbivores. Plant physiol 146: 852-858

Zieslin N, Ben-Zaken R (1993) Peroxidase activity and presence of phenolic substances in penduncles of rose flowers. Plant Physiol Biochem 31:333-339 


\section{Figure captions}

\section{Figure 1}

POD activity (IU g ${ }^{-1} \mathrm{FW}$ ) of groundnut genotypes infested with $H$. armigera and $A$. craccivora

Bars $($ Mean \pm SE) of same colors with similar alphabets are not statistically different at $(\mathrm{P}<0.05)$.

$\mathrm{H}=H$. armigera infested; $\mathrm{A}=$ A. craccivora infested; $\mathrm{C}=$ non-infested control; $\mathrm{FW}=$ fresh weight of leaf tissue.

\section{Figure 2}

PPO activity (IU g ${ }^{-1} \mathrm{FW}$ ) of groundnut genotypes infested with $H$. armigera and $A$. craccivora

Bars $($ Mean \pm SE) of same colors with similar alphabets are not statistically different at $(\mathrm{P}<0.05)$.

$\mathrm{H}=H$. armigera infested; $\mathrm{A}=$ A. craccivora infested; $\mathrm{C}=$ non-infested control; $\mathrm{FW}=$ fresh weight of leaf tissue.

\section{Figure 3}

PAL activity ( $\mu \mathrm{mol}$ cinnamic acid $\mathrm{mg}^{-1}$ protein) of groundnut genotypes infested with $H$. armigera and $A$. craccivora

Bars $($ Mean \pm SE) of same colors with similar alphabets are not statistically different at $(\mathrm{P}<0.05)$.

$\mathrm{H}=H$. armigera infested; $\mathrm{A}=A$. craccivora infested $\mathrm{C}=$ non-infested control

\section{Figure 4}

Catalase activity ( $\mu \mathrm{mol} \mathrm{min}^{-1} \mathrm{mg}^{-1}$ protein) of groundnut genotypes infested with $H$. armigera and A. craccivora

Bars $($ Mean $\pm \mathrm{SE})$ of same colors with similar alphabets are not statistically different at $(\mathrm{P}<0.05)$.

$\mathrm{H}=H$. armigera infested; $\mathrm{A}=$ A. craccivora infested $\mathrm{C}=$ non-infested control.

\section{Figure 5}

SOD activity (IU g ${ }^{-1} \mathrm{FW}$ ) of groundnut genotypes infested with $H$. armigera and $A$. craccivora 
Bars (Mean \pm SE) of same colors with similar alphabets are not statistically different at $(\mathrm{P}<0.05)$.

$\mathrm{H}=H$. armigera infested; $\mathrm{A}=A$. craccivora infested $; \mathrm{C}=$ non-infested control; $\mathrm{FW}=$ fresh weight of leaf tissue.

\section{Figure 6}

APX activity (IU mg ${ }^{-1}$ protein) of groundnut genotypes infested with $H$. armigera and A. craccivora

Bars (Mean \pm SE) of same colors with similar alphabets are not statistically different at $(\mathrm{P}<0.05)$.

$\mathrm{H}=H$. armigera infested; $\mathrm{A}=A$. craccivora infested $\mathrm{C}=$ non-infested control.

\section{Figure 7}

LOX activity (IU g ${ }^{-1} \mathrm{FW}$ ) of groundnut genotypes infested with $H$. armigera and A. craccivora

Bars (Mean \pm SE) of same colors with similar alphabets are not statistically different at $(\mathrm{P}<0.05)$.

$\mathrm{H}=H$. armigera infested; $\mathrm{A}=$ A. craccivora infested; $\mathrm{C}=$ non-infested control; $\mathrm{FW}=$ fresh weight of leaf tissue.

\section{Figure 8}

Total phenols ( $\mu$ mol GAE g ${ }^{-1} \mathrm{FW}$ ) of groundnut genotypes infested with H. armigera and A. craccivora

Bars (Mean \pm SE) of same colors with similar alphabets are not statistically different at $(\mathrm{P}<0.05)$.

$\mathrm{H}=H$. armiger infested; $\mathrm{A}=A$. craccivora infested; $\mathrm{C}=$ non-infested control; $\mathrm{GAE}=$ gallic acid equivalents; $\mathrm{FW}$ $=$ fresh weight of leaf tissue.

\section{Figure 9}

Condensed tannins ( $\mu \mathrm{mol} \mathrm{CE} \mathrm{g}^{-1} \mathrm{FW}$ ) of groundnut genotypes infested with H. armigera and A. craccivora

Bars (Mean $\pm \mathrm{SE}$ ) of same colors with similar alphabets are not statistically different at $(\mathrm{P}<0.05)$.

$\mathrm{H}=H$. armigera infested; $\mathrm{A}=A$. craccivora infested; $\mathrm{C}=$ non-infested control; $\mathrm{CE}=$ Catechin equivalents; $\mathrm{FW}=$ fresh weight of leaf tissue. 


\section{Figure 10}

$\mathrm{H}_{2} \mathrm{O}_{2}$ content $\left(\mu \mathrm{mol} \mathrm{g}{ }^{-1} \mathrm{FW}\right)$ of groundnut genotypes infested with $H$. armigera and A. craccivora

Bars $($ Mean \pm SE) of same colors with similar alphabets are not statistically different at $(\mathrm{P}<0.05)$.

$\mathrm{H}=H$. armigera infested $; \mathrm{A}=$ A. craccivora infested $; \mathrm{C}=$ non-infested control.

\section{Figure 11}

MDA content ( $\left.\mu \mathrm{mol} \mathrm{g}{ }^{-1} \mathrm{FW}\right)$ of groundnut genotypes infested with $H$. armigera and A. craccivora

Bars $($ Mean \pm SE) of same colors with similar alphabets are not statistically different at $(\mathrm{P}<0.05)$.

$\mathrm{H}=H$. armigera infested $; \mathrm{A}=A$. craccivora infested $\mathrm{C}=$ non-infested control

\section{Figure 12}

Protein content $\left(\mathrm{mg} \mathrm{g}^{-1} \mathrm{FW}\right)$ of groundnut genotypes infested with H. armigera and A. craccivora

Bars $($ Mean \pm SE) of same colors with similar alphabets are not statistically different at $(\mathrm{P}<0.05)$.

$\mathrm{H}=H$. armigera infested $; \mathrm{A}=A$. craccivora infested $\mathrm{C}=$ non-infested control 


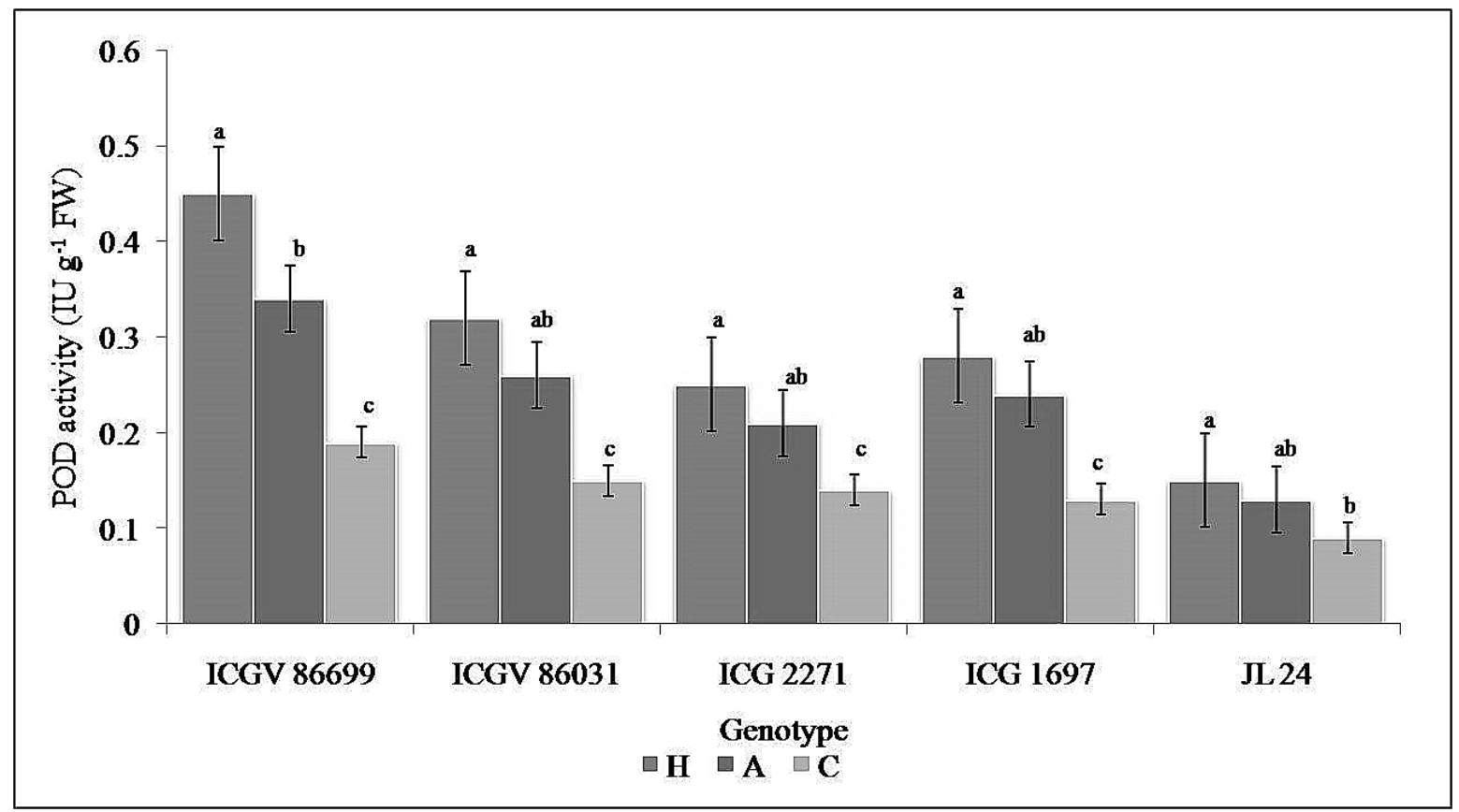

Fig. 1 


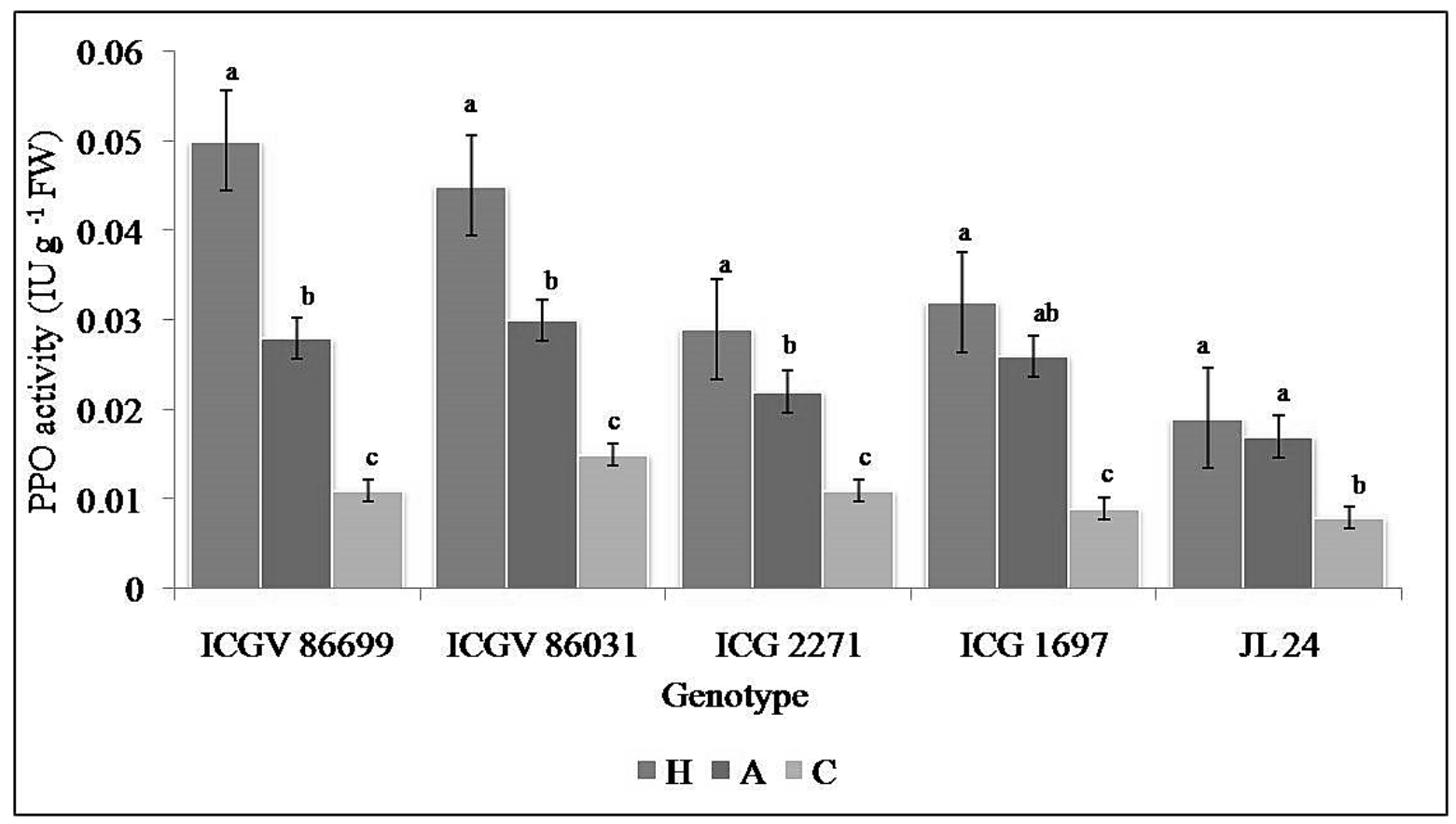

Fig. 2 


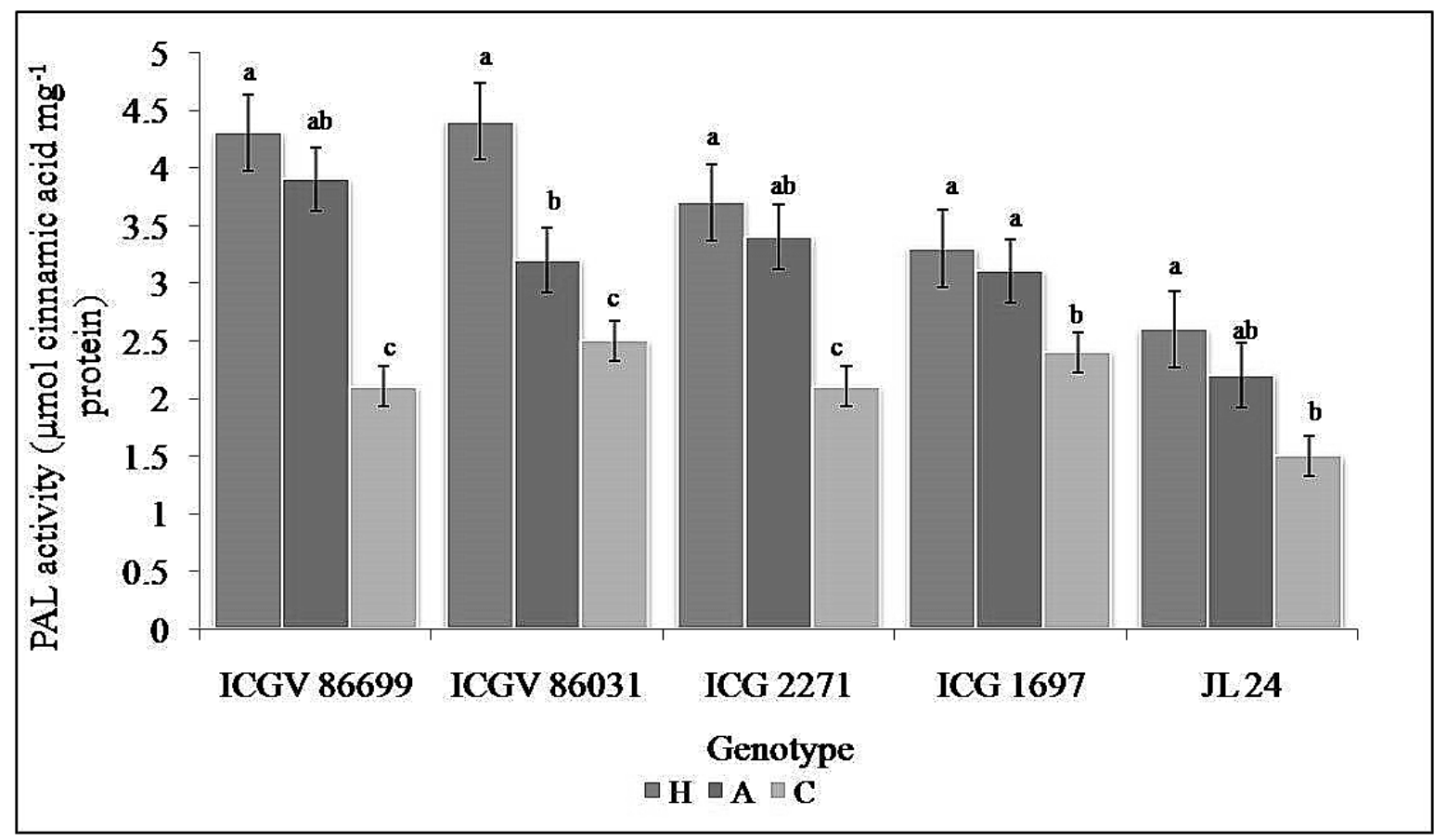

Fig. 3 


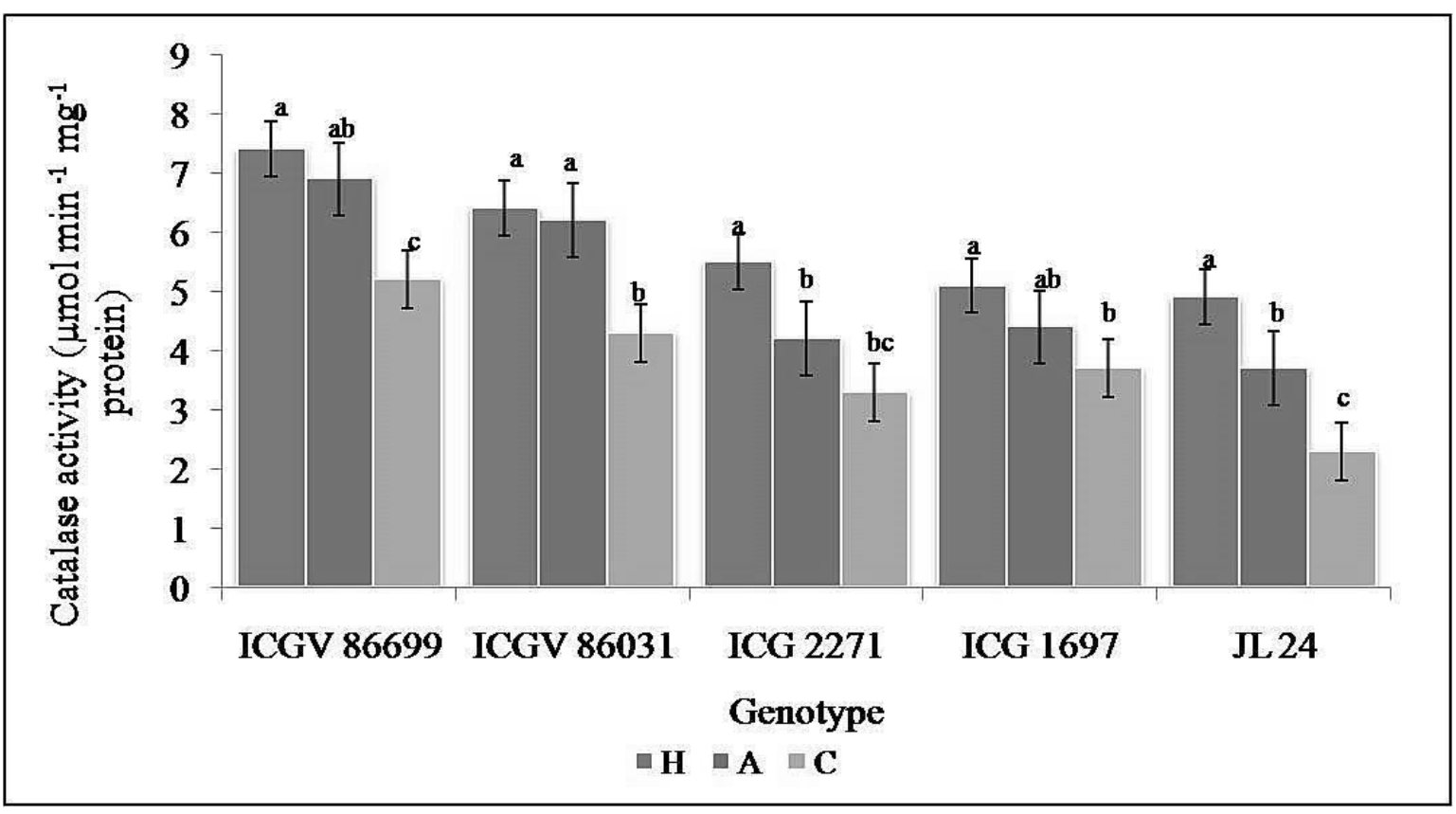

Fig. 4 


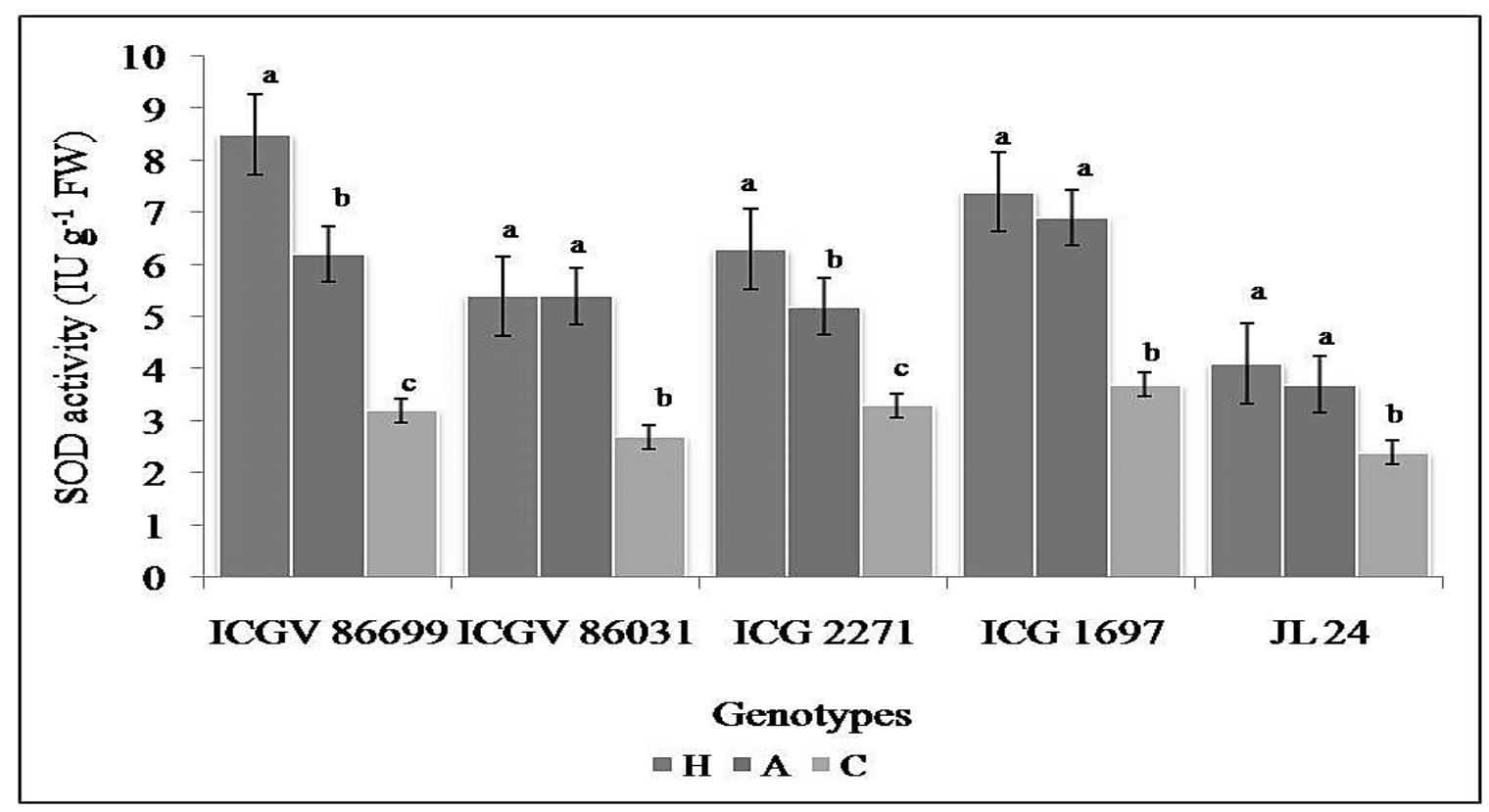

Fig. 5 


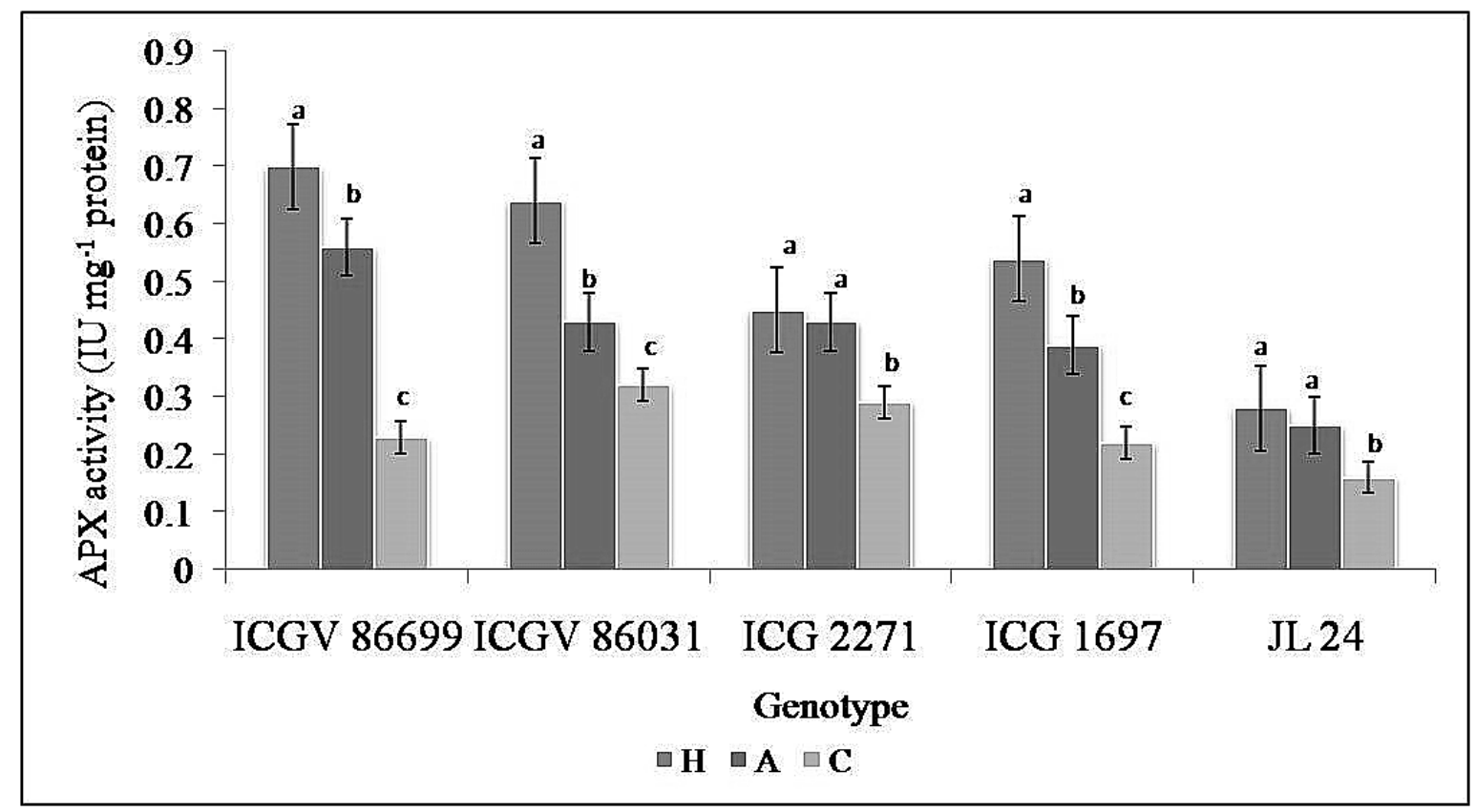

Fig. 6 


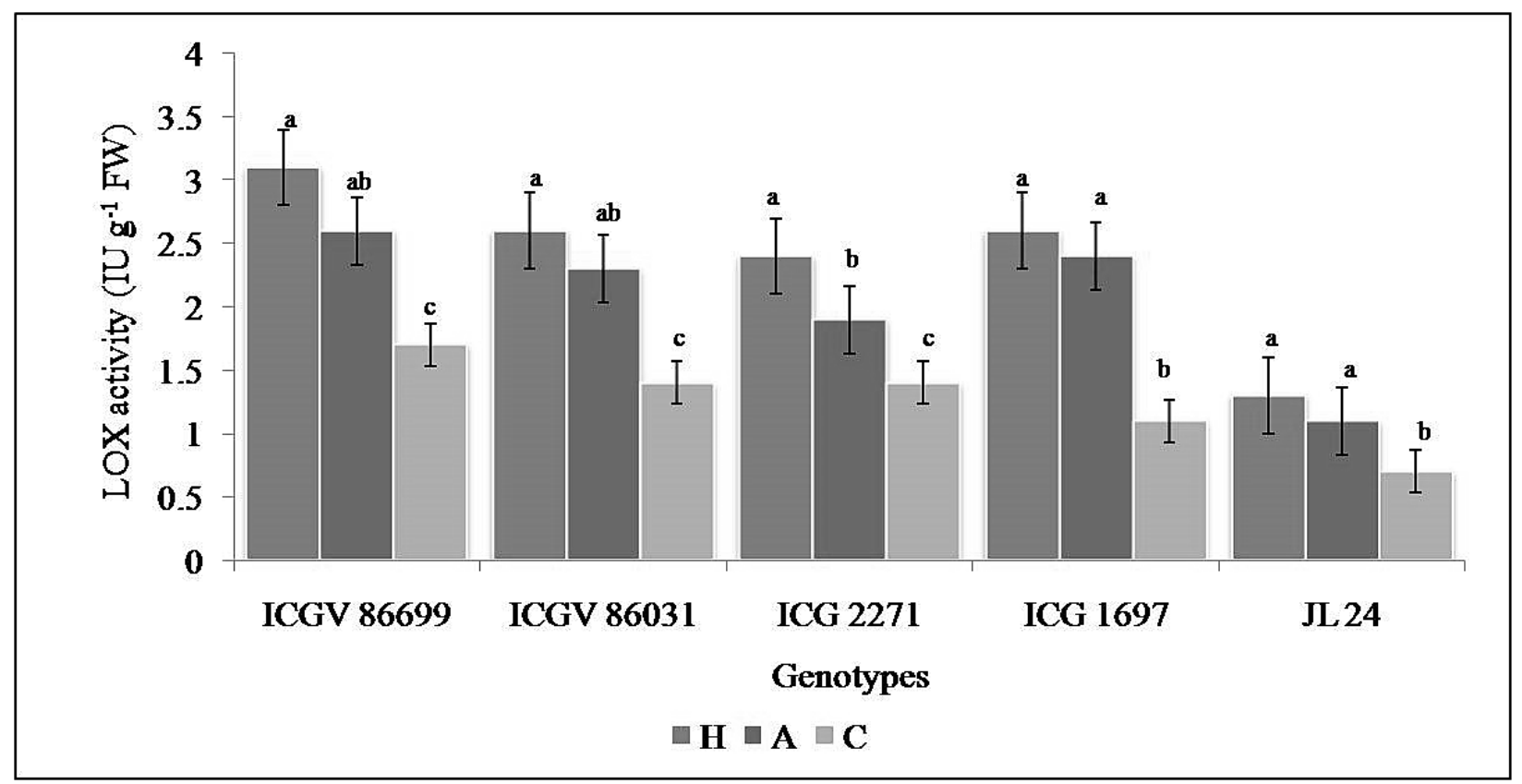

Fig. 7 


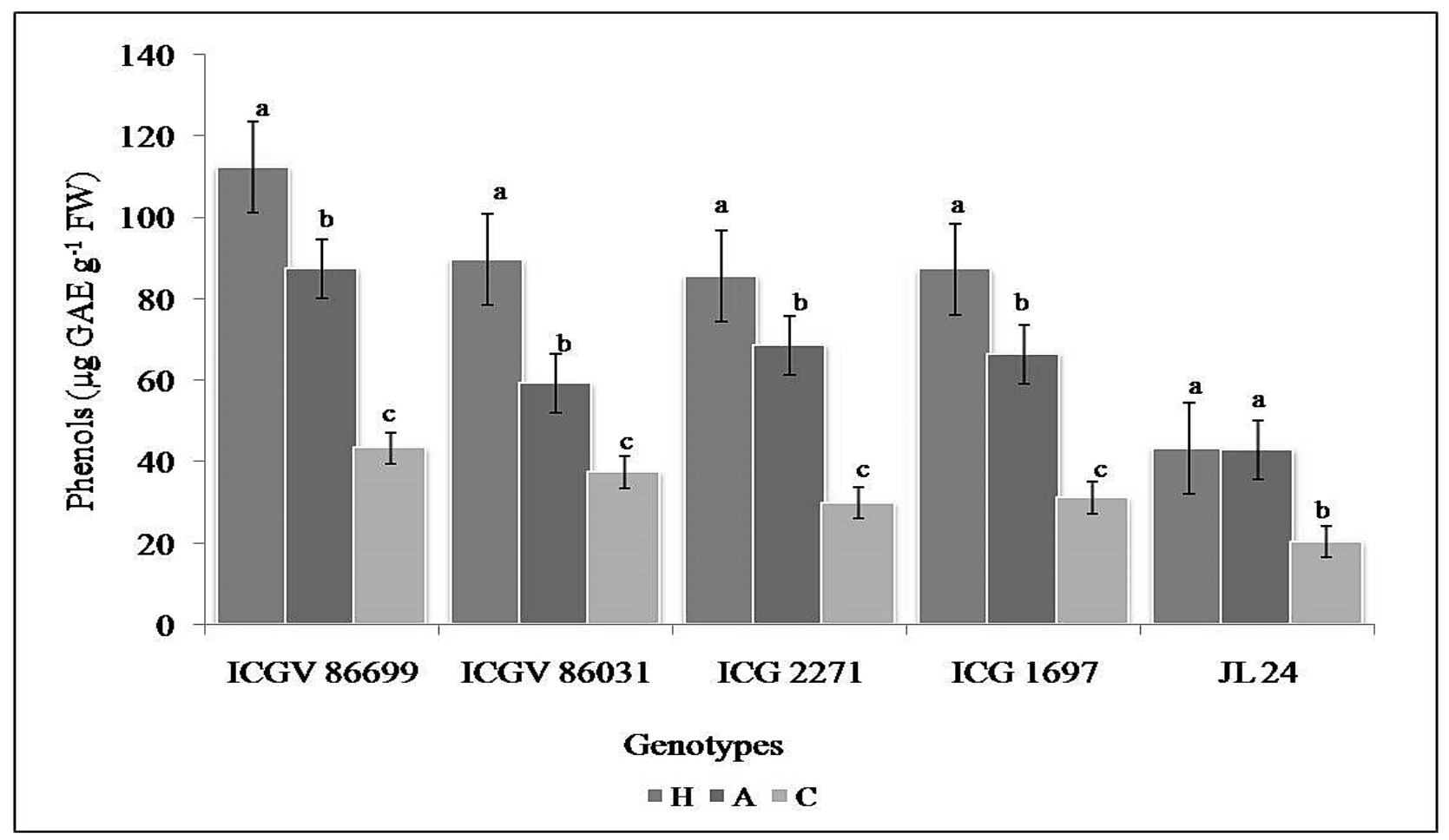

Fig. 8 


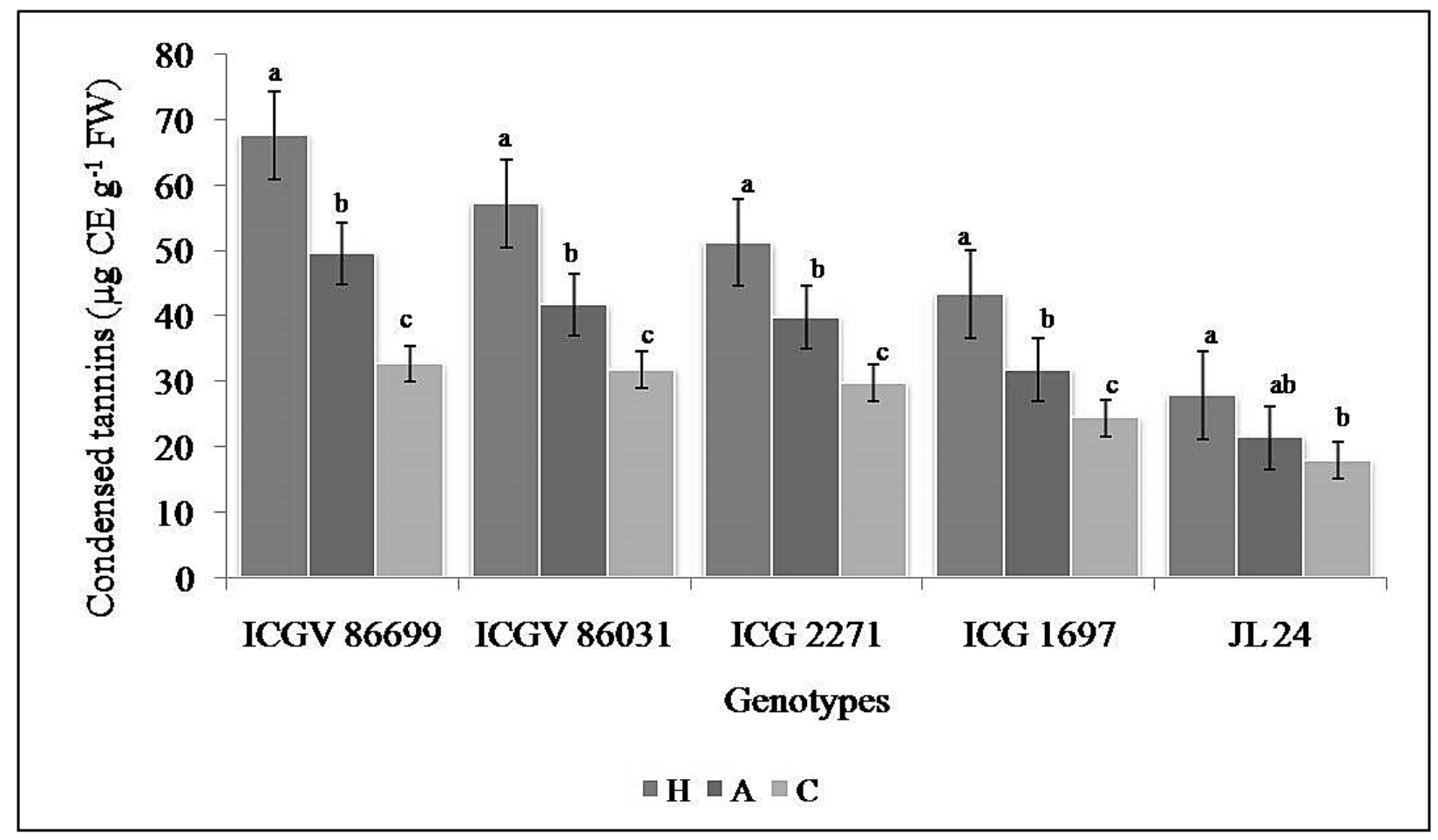

Fig. 9 


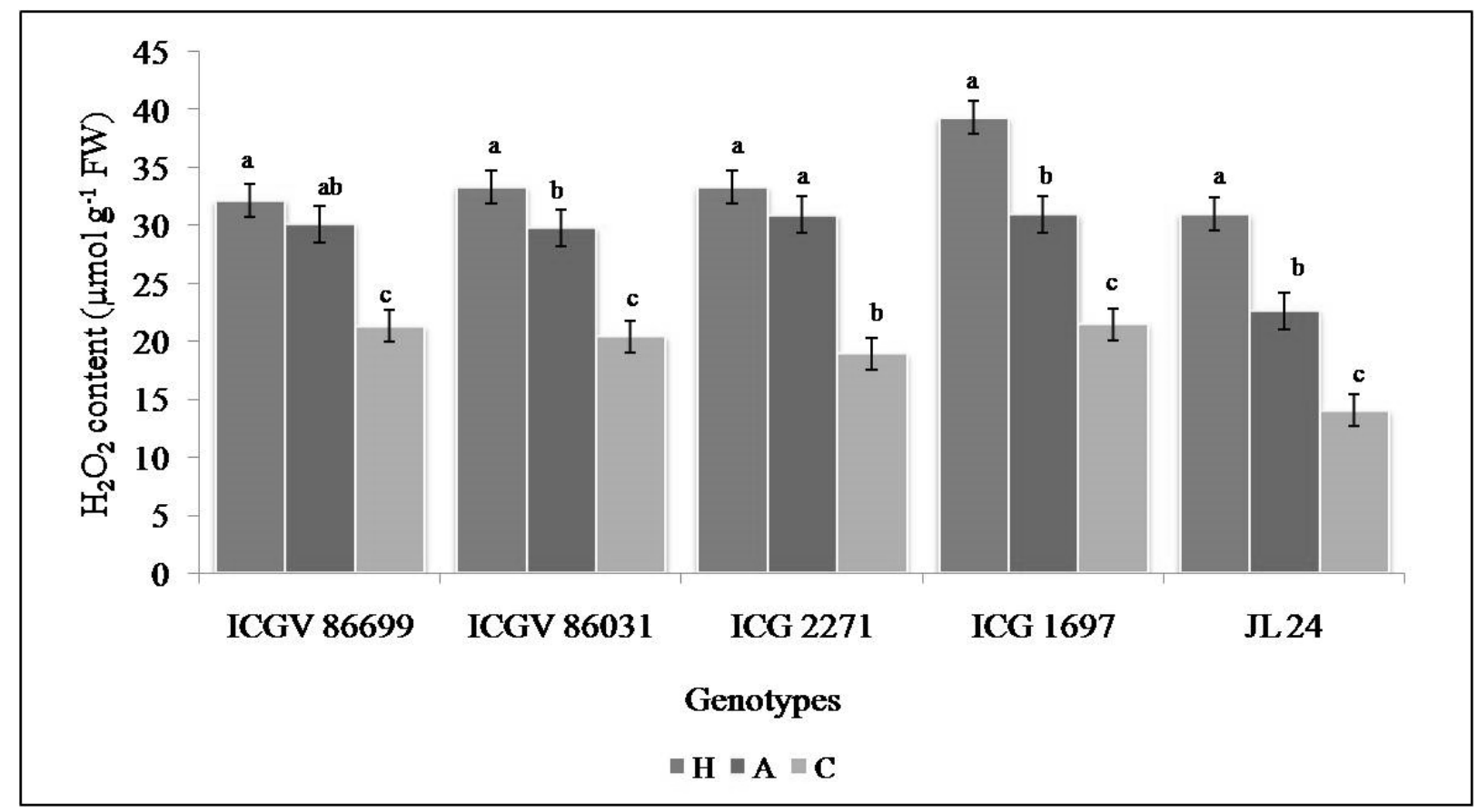

Fig. 10 


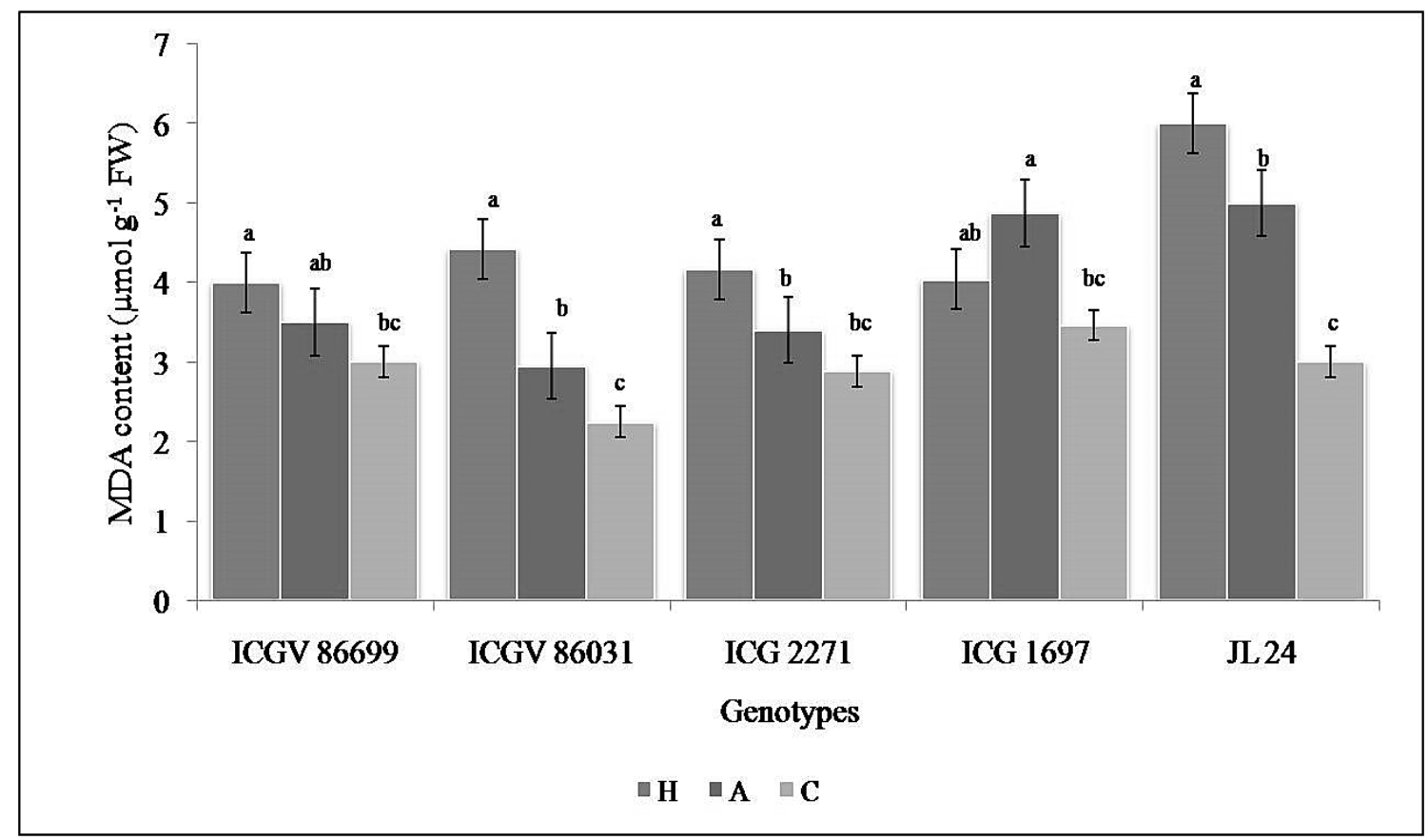

Fig. 11 


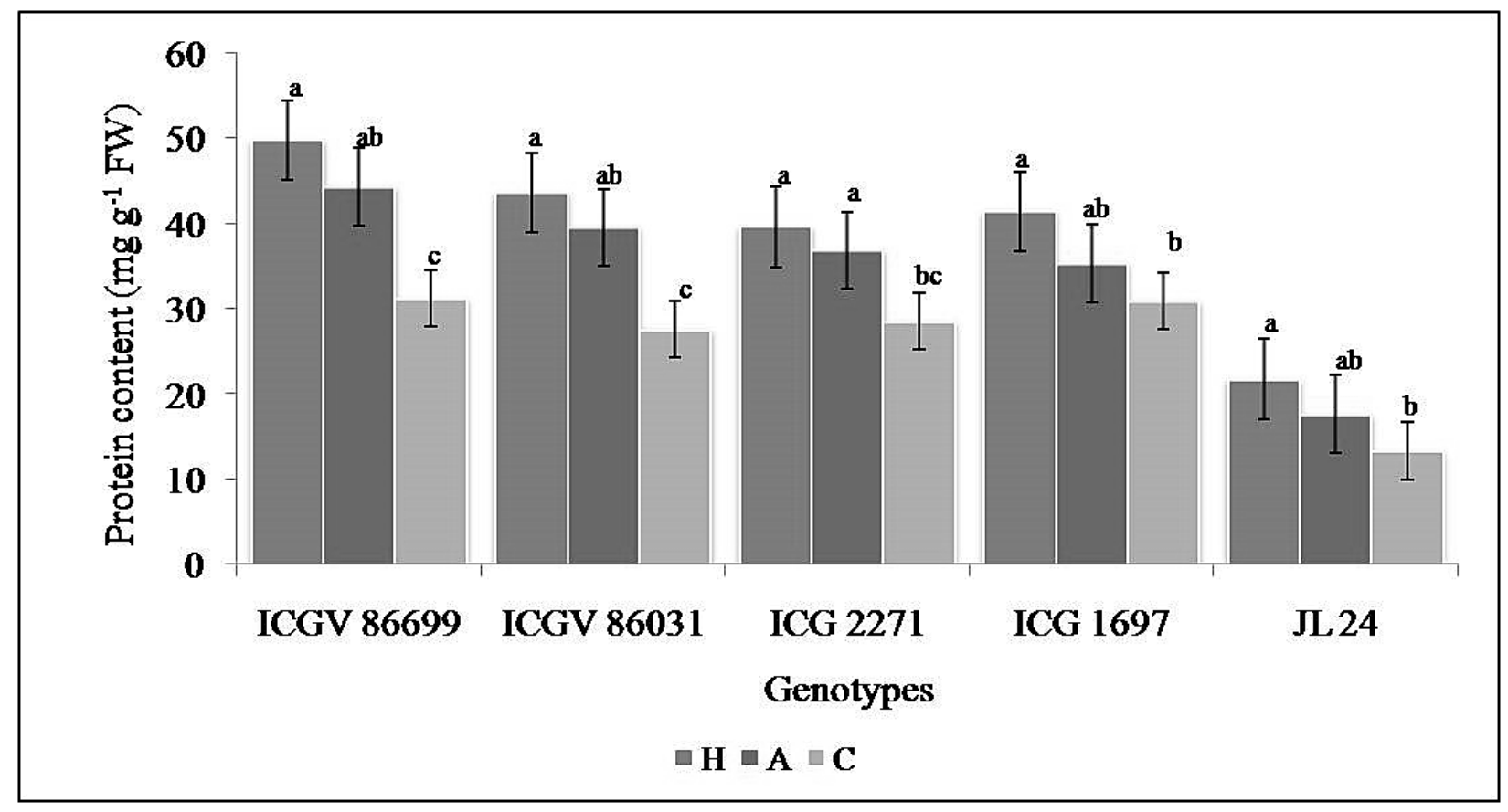

Fig. 12 
Table 1: Plant damage, larval survival and weight of $H$. armigera and A. craccivora after feeding on groundnut genotypes

\begin{tabular}{|c|c|c|c|c|c|}
\hline Genotypes & $\begin{array}{c}\text { Helicoverpa } \\
\mathrm{DR}^{\mathrm{x}}\end{array}$ & Larval survival (\%) & $\begin{array}{c}\text { Larval weight } \\
(\mathrm{mg})^{*}\end{array}$ & Aphid DR ${ }^{y}$ & $\begin{array}{l}\text { No. of } \\
\text { aphids }\end{array}$ \\
\hline ICGV 86699 & $2.8^{\mathrm{bc}}$ & $33.5 \pm 2.4^{\mathrm{c}}$ & $55.5 \pm 3.1^{\mathrm{bc}}$ & $2.5^{\mathrm{b}}$ & $31.5 \pm 3.5^{b}$ \\
\hline ICGV 86031 & $3.5^{\mathrm{b}}$ & $39.4 \pm 2.8^{\mathrm{bc}}$ & $68.9 \pm 6.9^{b}$ & $2.6^{\mathrm{b}}$ & $27.8 \pm 2.8^{\mathrm{b}}$ \\
\hline ICG 2271 & $4.2^{\mathrm{b}}$ & $45.6 \pm 4.6^{\mathrm{b}}$ & $65.6 \pm 5.2^{\mathrm{b}}$ & $2.3^{\mathrm{b}}$ & $37.8 \pm 4.6^{\mathrm{b}}$ \\
\hline ICG 1697 & $3.8^{\mathrm{b}}$ & $48.3 \pm 3.4^{\mathrm{b}}$ & $67.4 \pm 4.7^{\mathrm{b}}$ & $2.0^{\mathrm{b}}$ & $19.0 \pm 3.3^{\mathrm{c}}$ \\
\hline JL 24 & $7.5^{\mathrm{a}}$ & $77.5 \pm 7.6^{\mathrm{a}}$ & $95.5 \pm 6.8^{\mathrm{a}}$ & 4. $2^{\mathrm{a}}$ & $56.5 \pm 6.2^{\mathrm{a}}$ \\
\hline
\end{tabular}

Values (Mean \pm SEM) carrying same alphabet(s) within a column are not significantly different.

${ }^{\mathrm{x}} \mathrm{DR}=$ Helicoverpa damage rating to a scale $1-9(1 \leq 10 \%$ and $9 \geq 90 \%) 6$ days after infestation

* Weight per five larva at the time of recovery.

${ }^{\mathbf{y}}=$ Aphid damage rating to a scale $1-5(1=$ highly resistant, and $5=$ highly susceptible $)$ 